\title{
Plan
}

Project No. 29412

\section{Advanced Reactor Technologies Program Management Plan}

The INL is a

U.S. Department of Energy

National Laboratory

operated by

Battelle Energy Alliance

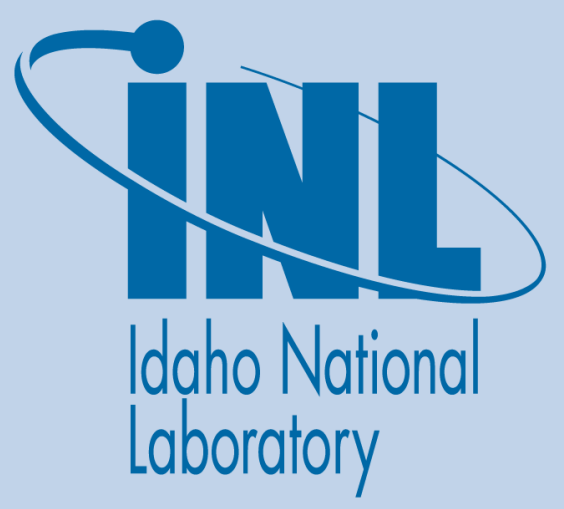

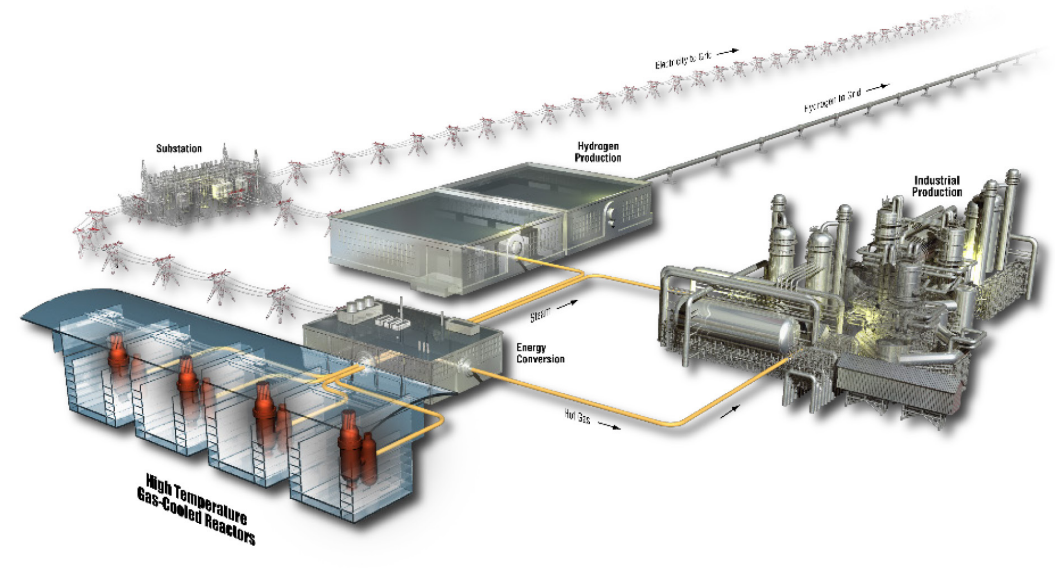




\begin{tabular}{|c|lll|}
\hline $\begin{array}{c}\text { ADVANCED REACTOR TECHNOLOGIES } \\
\text { PROGRAM MANAGEMENT PLAN }\end{array}$ & $\begin{array}{l}\text { Identifier: } \\
\text { Revision: }\end{array}$ & $\begin{array}{l}\text { PLN-2494 } \\
17\end{array}$ & \\
& Effective Date: & $02 / 07 / 2019$ & Page: ii of ix \\
\hline
\end{tabular}

ART Program

Plan

eCR Number: 665909

Manual: NGNP

Prepared by::

Nure Veos

Diane V. Croson, Deputy Director

INL Advanced Reactor Technologies

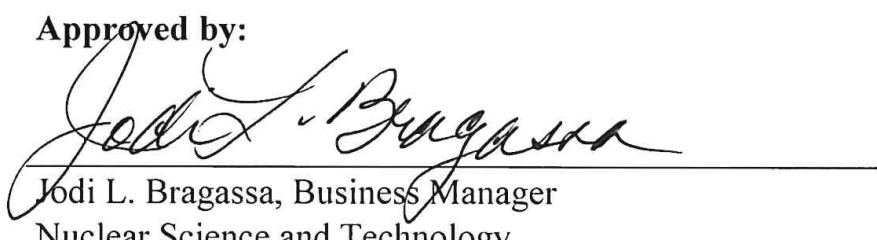

Nuclear Science and Technology

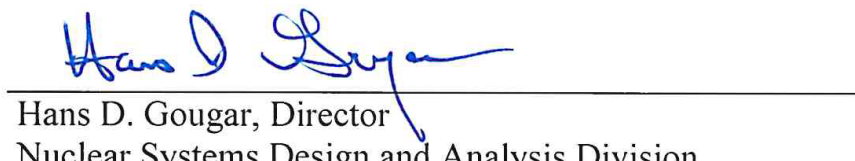

Nuclear Systems Design and Analysis Division

MI Shayp

Michelle T. Sharp, Quality Engineer

INL Quality Assurance
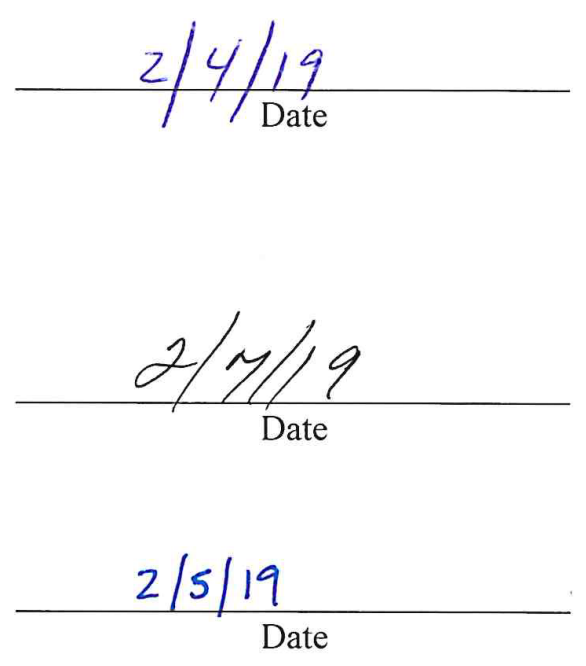

$\frac{2 / 5 / 19}{\text { Date }}$ 


\begin{tabular}{|c|lll|}
\hline $\begin{array}{c}\text { ADVANCED REACTOR TECHNOLOGIES } \\
\text { PROGRAM MANAGEMENT PLAN }\end{array}$ & Identifier: & PLN-2494 & \\
& Revision: & 17 & \\
& Effective Date: & $02 / 07 / 2019$ & Page: iii of ix \\
\hline
\end{tabular}

\section{REVISION LOG}

\begin{tabular}{|c|c|c|c|}
\hline Rev. & Date & Affected Pages & Revision Description \\
\hline 0 & $04 / 18 / 2008$ & All & New issue. \\
\hline 1 & $06 / 02 / 2008$ & 12 & Revised to reflect new organization chart. \\
\hline 2 & $04 / 30 / 2009$ & All & 2009 revision. \\
\hline 3 & $05 / 30 / 2009$ & $34-43$ and 47 & $\begin{array}{l}\text { Updated work breakdown structure and Next Generation } \\
\text { Nuclear Plant research and development Fiscal year } 2009 \\
\text { integrated priority list. }\end{array}$ \\
\hline 4 & $10 / 29 / 2010$ & All & Routine update. \\
\hline 5 & $02 / 04 / 2011$ & 19 and 20 & $\begin{array}{l}\text { Updated baseline change control guidelines } \\
\text { (CCN 223142). }\end{array}$ \\
\hline 6 & $08 / 02 / 2011$ & 14 and 19 & $\begin{array}{l}\text { Updated organization chart. Changed LWP- } 7400 \text { to } \\
\text { MCP- } 7400 \text {. }\end{array}$ \\
\hline 7 & $02 / 27 / 2012$ & All & $\begin{array}{l}\text { Revised to reflect results of routine update and added } \\
\text { Next Generation Nuclear Plant engineering and licensing } \\
\text { functions. }\end{array}$ \\
\hline 8 & $06 / 11 / 2012$ & 17,46 & $\begin{array}{l}\text { VHTR TDO organization chart updated, } \\
\text { Work package manager updated. }\end{array}$ \\
\hline 9 & $06 / 19 / 2012$ & iv, 2 & $\begin{array}{l}\text { Changed Licensing director to Regulatory Affairs } \\
\text { director. }\end{array}$ \\
\hline 10 & $07 / 23 / 2012$ & All & $\begin{array}{l}\text { Changes made to reflect transition from NGNP Project to } \\
\text { VHTR TDO program and ensure consistency with } \\
\text { PLN-2690 QAPP. }\end{array}$ \\
\hline 11 & $3 / 19 / 2013$ & All & Routine update. \\
\hline 12 & $3 / 31 / 2014$ & All & Routine update. \\
\hline 13 & $03 / 04 / 2015$ & All & $\begin{array}{l}\text { Revised to reflect results of routine update and name } \\
\text { change from VHTR TDO to ART program. }\end{array}$ \\
\hline 14 & $05 / 05 / 2015$ & 20,45 & $\begin{array}{l}\text { On Table } 1 \text { removed the words "weekly summary and" } \\
\text { In Appendix A changed Ohio State to Oregon State. }\end{array}$ \\
\hline 15 & $04 / 17 / 2018$ & All & $\begin{array}{l}\text { Revised to reflect new organization structure and } \\
\text { management processes under DOE-NE-4 Nuclear } \\
\text { Technology Research and Development. } \\
\text { Changed program name from INL ART TDO to ART. }\end{array}$ \\
\hline 16 & $05 / 15 / 2018$ & 23 & Removed reference to external audit. \\
\hline 17 & $02 / 07 / 2019$ & All & $\begin{array}{l}\text { Revised to reflect transition from DOE-NE-4 to DOE- } \\
\text { NE-52, Office of Advanced Reactor Deployment, and } \\
\text { changes to the work structure. }\end{array}$ \\
\hline
\end{tabular}




\begin{tabular}{|c|lll|}
\hline $\begin{array}{c}\text { ADVANCED REACTOR TECHNOLOGIES } \\
\text { PROGRAM MANAGEMENT PLAN }\end{array}$ & $\begin{array}{l}\text { Revision: } \\
\text { Effective Date: }\end{array}$ & $\begin{array}{l}\text { PLN-2494 } \\
\text { RAT/2019 }\end{array}$ & Page: iv of ix \\
\hline
\end{tabular}

\section{EXECUTIVE SUMMARY}

The Advanced Reactor Technologies (ART) program grew out of earlier Department of Energy efforts to promote next-generation, small modular, and other advanced reactor concepts. It is now sponsored by Office of Advanced Reactor Deployment, NE-52. Because of its peculiar genesis, the program resides at multiple national laboratories and brings in researchers from subcontracting entities and universities. This creates a need for Idaho National Laboratory's (INL's) ART to authorize and define work through memorandum purchase orders, inter-entity work orders, and subcontracts.

ART manages research and development (R\&D) for the Gas-Cooled Reactors (GCRs) Campaign and other advanced-reactor technologies and ensures that Nuclear Regulatory Commission (requirements and stakeholder needs are factored into the R\&D activities. The GCR Campaign supports the Next Generation Nuclear Plant High Temperature Reactor as outlined in the Energy Policy Act of $2005^{1}$ by integrating the following major program elements of research and licensing:

- Fuel Development and Qualification: nuclear fuel development, characterization, and qualification

- High-temperature Materials: materials selection, development, testing, and qualification

- Graphite Development and Qualification: source selection, development, testing, and qualification

- Design Methods and Validation: reactor and balance-of-plant design, engineering, safety analysis, verification, and validation

- Licensing: NRC regulatory framework development and implementation.

Other ART program elements within the ART include the following:

- Microreactors: development of small reactors for non-traditional applications, including remote terrestrial locations and space

- Fast Reactors: advancement of fast-reactor technologies for closed fuel cycle and power production applications

- Molten Salt Reactors: development of MSR technology and advocacy of establishment of the U.S. MSR industry

- Generation IV International Forum: foster and leverage HTR technology R\&D across the international community.

The ART director works with the ART deputy director, ART project managers, technical leads, ART licensing director and Quality Assurance engineer to integrate and ensure all requirements are well defined, understood, and documented. The ART deputy director works with ART project and technical leads and program support staff to ensure effective annual planning and execution of work and to oversee the assignment of appropriate resources to meet the R\&D needs of the ART program. 


\begin{tabular}{|c|c|c|c|}
\hline $\begin{array}{l}\text { ADVANCED REACTOR TECHNOLOGIES } \\
\text { PROGRAM MANAGEMENT PLAN }\end{array}$ & $\begin{array}{l}\text { Identifier: } \\
\text { Revision: } \\
\text { Effective Date: }\end{array}$ & $\begin{array}{l}\text { PLN-2494 } \\
17 \\
02 / 07 / 2019\end{array}$ & Page: v of ix \\
\hline
\end{tabular}

\section{CONTENTS}

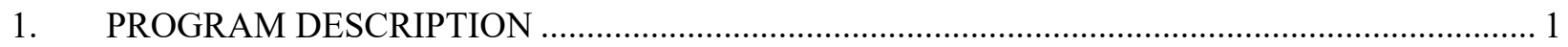

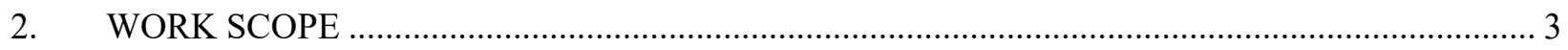

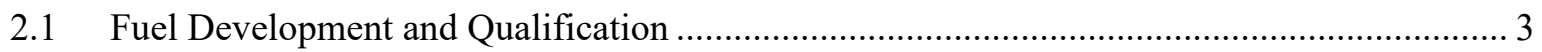

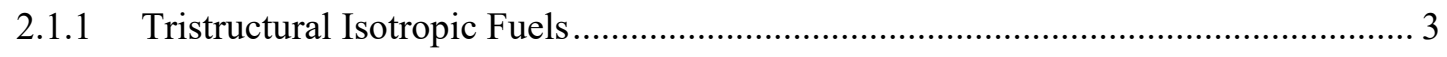

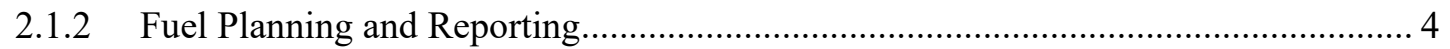

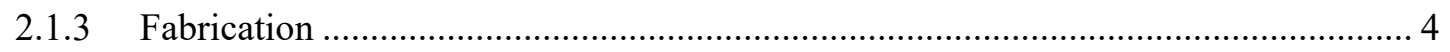

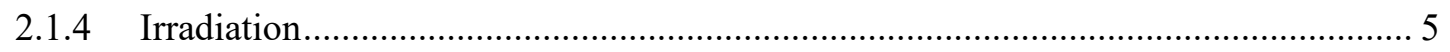

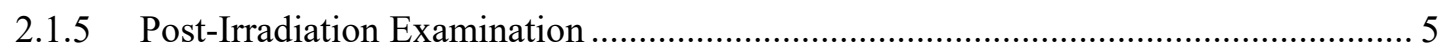

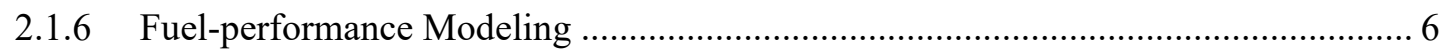

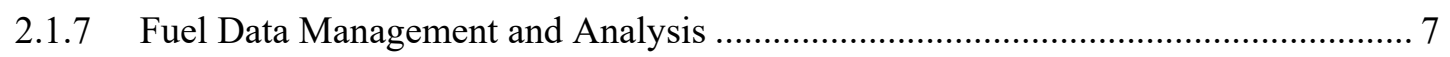

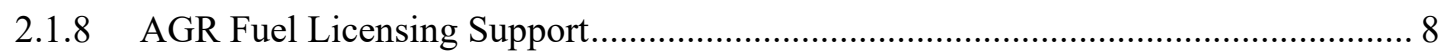

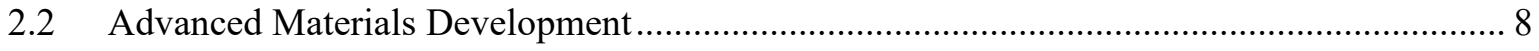

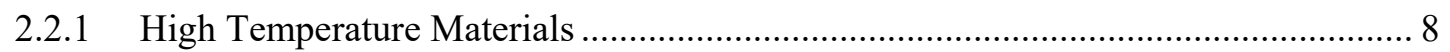

2.2.2 Graphite Research and Development ............................................................... 9

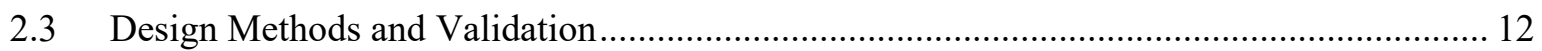

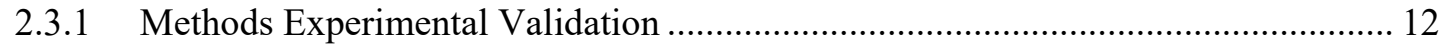

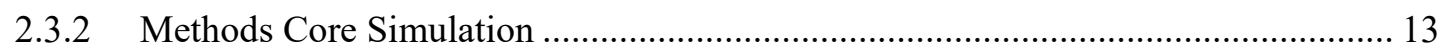

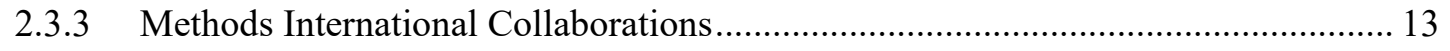

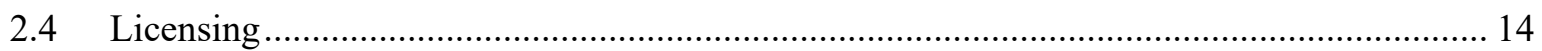

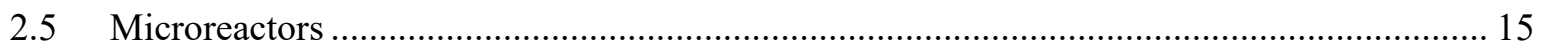

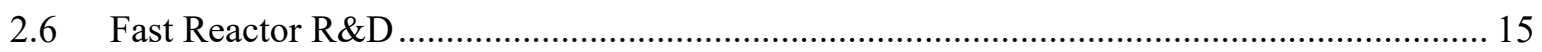

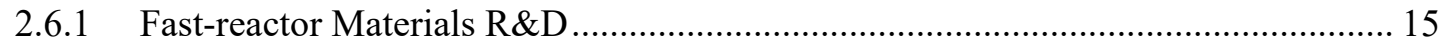

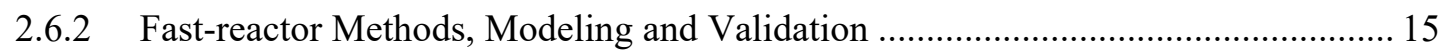

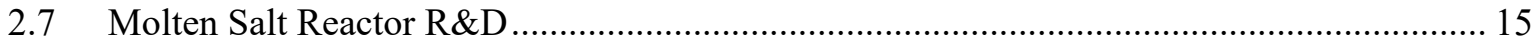

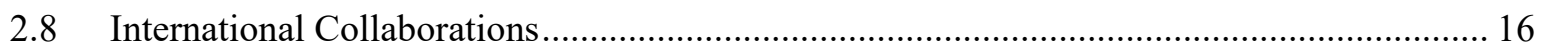

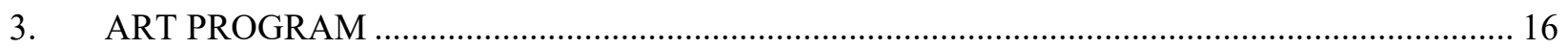

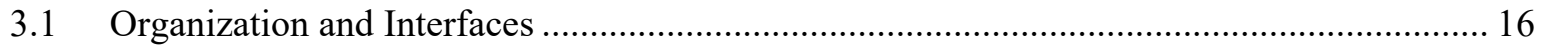

3.2 Roles, Responsibilities, Accountabilities, and Authorities ................................................... 17

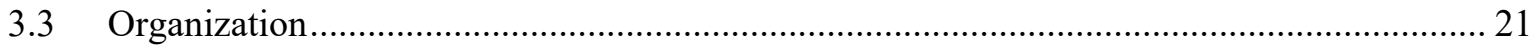

3.4 Program Interfaces: External and Internal …............................................................. 22

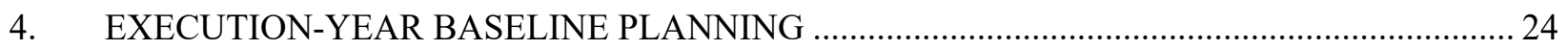

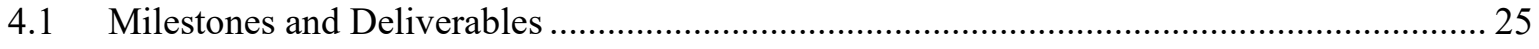

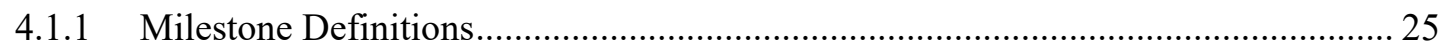

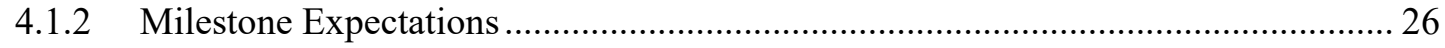

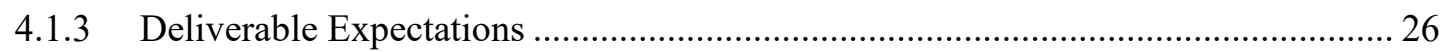

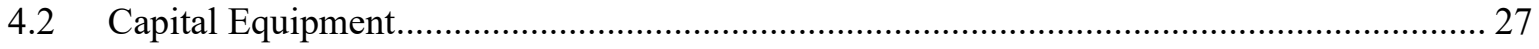




\begin{tabular}{|c|c|c|c|}
\hline $\begin{array}{l}\text { ADVANCED REACTOR TECHNOLOGIES } \\
\text { PROGRAM MANAGEMENT PLAN }\end{array}$ & $\begin{array}{l}\text { Identifier: } \\
\text { Revision: } \\
\text { Effective Date: }\end{array}$ & $\begin{array}{l}\text { PLN-2494 } \\
17 \\
02 / 07 / 2019\end{array}$ & Page: vi of ix \\
\hline
\end{tabular}

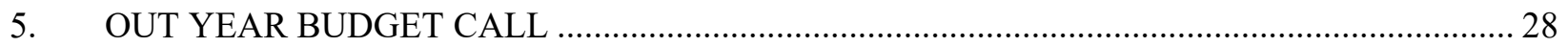

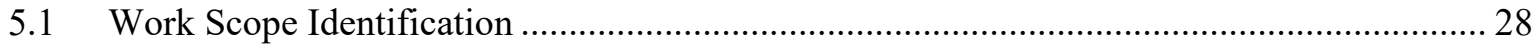

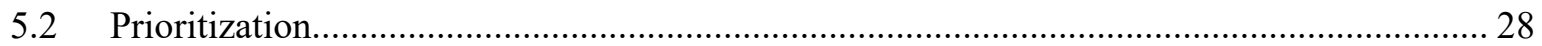

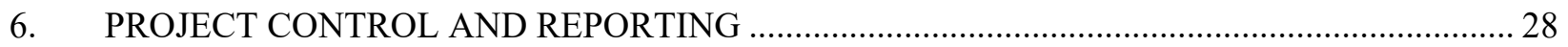

6.1 Work Breakdown Structure and Dictionary ................................................................... 28

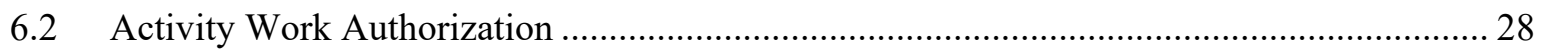

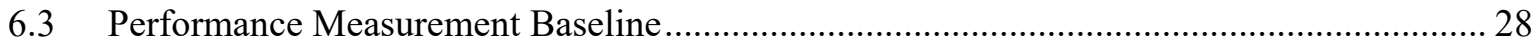

6.3.1 Earned Value Management Level of Effort ................................................................. 29

6.3.2 Earned-value Management Percent Complete .......................................................... 29

6.3.3 Milestone Status Performance Measurement ............................................................... 30

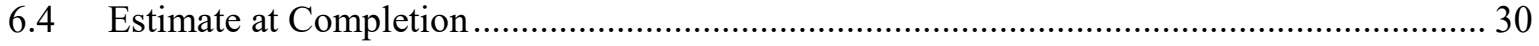

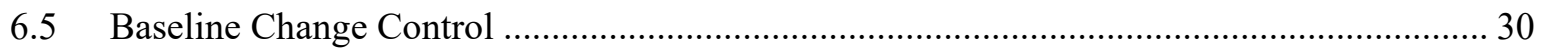

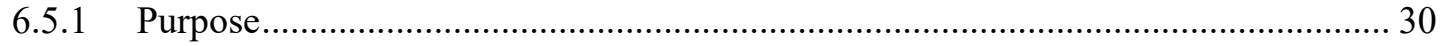

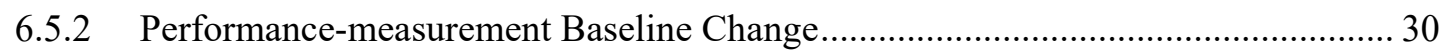

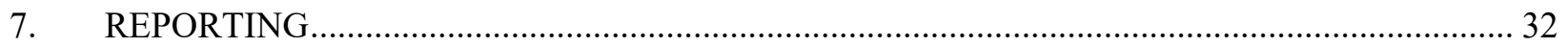

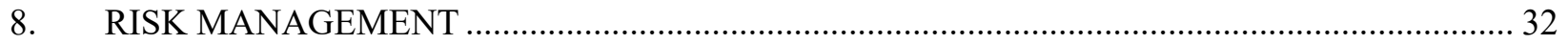

9. ENVIRONMENTAL, SAFETY, HEALTH AND QUALITY ASSURANCE ….......................... 32

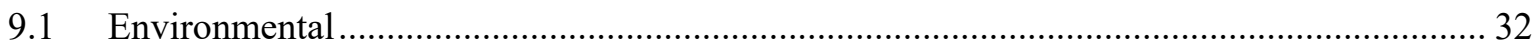

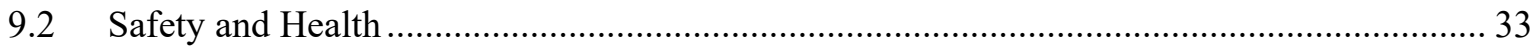

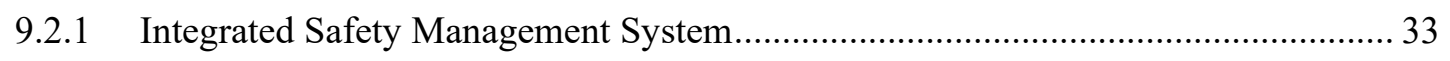

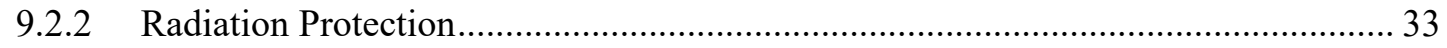

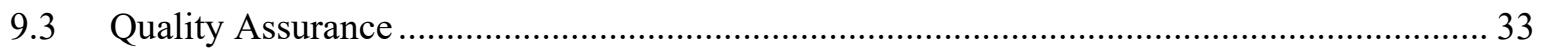

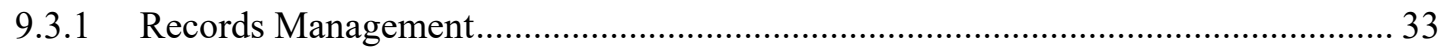

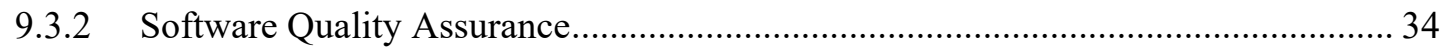

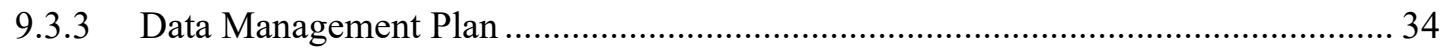

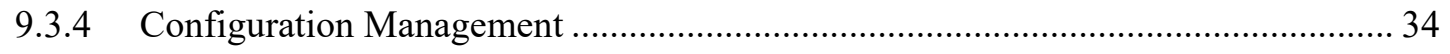

9.3.5 Personnel Indoctrination, Training, and Qualification........................................... 34

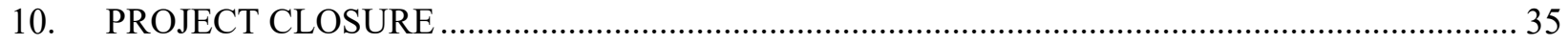

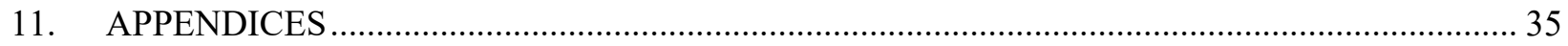

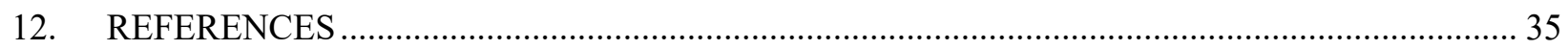

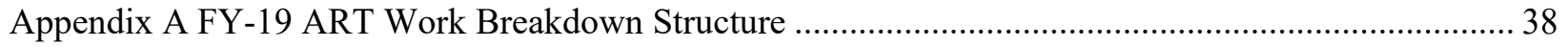

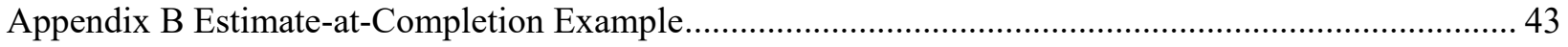




\begin{tabular}{|c|c|c|c|}
\hline $\begin{array}{l}\text { ADVANCED REACTOR TECHNOLOGIES } \\
\text { PROGRAM MANAGEMENT PLAN }\end{array}$ & $\begin{array}{l}\text { Identifier: } \\
\text { Revision: } \\
\text { Effective Date: }\end{array}$ & $\begin{array}{l}\text { PLN-2494 } \\
17 \\
02 / 07 / 2019\end{array}$ & Page: vii of ix \\
\hline
\end{tabular}

\section{FIGURES}

Figure 1. Advanced Reactor Technologies organization.

\section{TABLES}

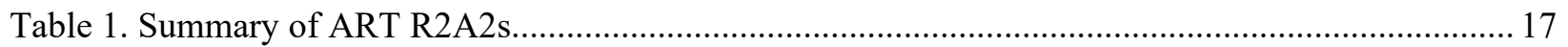

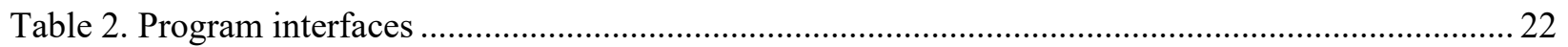

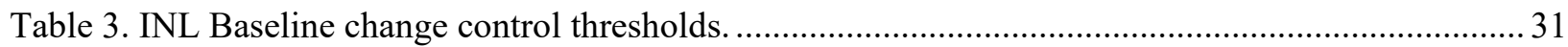

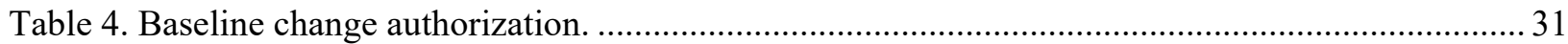




\begin{tabular}{|c|lll|}
\hline $\begin{array}{c}\text { ADVANCED REACTOR TECHNOLOGIES } \\
\text { PROGRAM MANAGEMENT PLAN }\end{array}$ & Identifier: & PLN-2494 & \\
& Revision: & 17 & \\
& Effective Date: & $02 / 07 / 2019$ & Page: viii of ix \\
\hline
\end{tabular}

\section{ACRONYMS}

ACWP actual cost of work performed

AGC advanced graphite creep

AGR Advanced Gas Reactor

AM

Advanced Materials

ANL

Argonne National Laboratory

ART

Advanced Reactor Technologies

ASME

American Society of Mechanical Engineers

ASTRID Advanced Sodium Technological Reactor for Industrial Demonstration

ATR

Advanced Test Reactor

$\mathrm{BCP}$

Baseline Change Proposal

BCWP

budgeted cost of work performed

CAM

control account manager

CAP

control account plan

CFD

computational fluid dynamics

$\mathrm{CV}$

cost variance

DOE

Department of Energy

DOE-NE

Department of Energy Office of Nuclear Energy

DTF

designed-to-fail

EAC

estimate at completion

EC

energy conversion

EPRI

Electric Power Research Institute

FR

fast reactor

FY

fiscal year

GCR

Gas-Cooled Reactors

GIF

Generation IV International Forum

HDG High Dose Graphite

HFEF

Hot Fuel Examination Facility

HFIR

High Flux Isotope Reactor

HTGR high temperature gas-cooled reactor

HTM

high temperature materials

HTR

high temperature reactor

HTV

high temperature vessel

IEWO

inter-entity work order

INL

Idaho National Laboratory

IPL integrated priority list

ISMS Integrated Safety Management System

IWAD INL work authorization document

LRS Lab Review System 


\begin{tabular}{|c|lll|}
\hline $\begin{array}{c}\text { ADVANCED REACTOR TECHNOLOGIES } \\
\text { PROGRAM MANAGEMENT PLAN }\end{array}$ & Identifier: & PLN-2494 & \\
& Revision: & 17 & \\
& Effective Date: & $02 / 07 / 2019$ & Page: ix of ix \\
\hline
\end{tabular}

\begin{tabular}{|c|c|}
\hline LMP & Licensing Modernization Project \\
\hline LOE & level of effort \\
\hline MFC & Materials and Fuels Complex \\
\hline MPO & memorandum purchase order \\
\hline MR & microreactor \\
\hline MSR & molten salt reactor \\
\hline NDMAS & Nuclear Data Management and Analysis System \\
\hline $\mathrm{NE}$ & (Department of Energy) Office of Nuclear Energy \\
\hline NEI & Nuclear Energy Institute \\
\hline NGNP & Next Generation Nuclear Plant \\
\hline NIRMA & National Information and Records Management Association Incorporated \\
\hline NPR & New Production Reactor \\
\hline NQA & Nuclear Quality Assurance \\
\hline $\mathrm{NRC}$ & Nuclear Regulatory Commission \\
\hline NS\&T & Nuclear Science and Technology \\
\hline NTD & national technical directors \\
\hline NTRD & Nuclear Technology Research and Development \\
\hline ORNL & Oak Ridge National Laboratory \\
\hline $\mathrm{PFC}$ & project and financial controls \\
\hline PICS:NE & Project Information Collection System: Nuclear Energy \\
\hline PIE & post-irradiation examination \\
\hline PIRT & phenomena identification and ranking tables \\
\hline PMB & performance-measurement baseline \\
\hline QA & quality assurance \\
\hline $\mathrm{R} \& \mathrm{D}$ & research and development \\
\hline $\mathrm{R} 2 \mathrm{~A} 2 \mathrm{~s}$ & roles, responsibilities, accountabilities, and authorities \\
\hline $\mathrm{RS}$ & regulatory support \\
\hline SV & schedule variance \\
\hline TAL & technology area lead \\
\hline TRISO & tristructural isotropic \\
\hline U.S. & United States \\
\hline $\mathrm{UCO}$ & uranium oxycarbide \\
\hline $\mathrm{V} \& \mathrm{~V}$ & verification and validation \\
\hline VHTR & Very High Temperature Reactor \\
\hline WP & work package \\
\hline WPM & work-package manager \\
\hline
\end{tabular}




\begin{tabular}{|c|c|c|c|}
\hline $\begin{array}{l}\text { ADVANCED REACTOR TECHNOLOGIES } \\
\text { PROGRAM MANAGEMENT PLAN }\end{array}$ & $\begin{array}{l}\text { Identifier: } \\
\text { Revision: } \\
\text { Effective Date: }\end{array}$ & $\begin{array}{l}\text { PLN-2494 } \\
17 \\
02 / 07 / 2019\end{array}$ & Page: 1 of 43 \\
\hline
\end{tabular}

\section{PROGRAM DESCRIPTION}

The Advanced Reactor Technologies (ART) Program was formed in fiscal year (FY)-15 as a Department of Energy (DOE) Office of Nuclear Energy (NE) consolidation of the Next Generation Nuclear Plant (NGNP), Small Modular Reactors, and Advanced Reactor Concepts programs. In FY-16, the DOE ART Programs transitioned to NE-4 Nuclear Technology Research and Development, and was fully integrated into NE-4 at the start of FY-17. Subsequently, the ART Program transitioned from NE-4 to NE-52, Office of Advanced Reactor Deployment at the start of FY-19. The mission of ART is to develop new and advanced reactor designs and technologies that advance the state of reactor technology to improve competitiveness and support meeting the nation's energy, environmental, and national security needs. The ART Program crosses multiple national laboratories and is led by co-national technical directors (co-NTDs) from Idaho National Laboratory (INL), Argonne National Laboratory (ANL), and Oak Ridge National Laboratory (ORNL). ART manages that portion of the DOE-NE ART program work scope that is funded at INL and at other national laboratories via memorandum purchase orders (MPO) with INL. Therefore, this program-management plan addresses all of the work scope for which ART is responsible. ART was established at INL to coordinate the research and development (R\&D) activities required to design and license the first high-temperature reactors (HTRs) and perform other R\&D projects to support DOE advanced-reactor technologies. The intent of ART is to staff ART program with the right people to accomplish the work, regardless of location or affiliation. Participants include a number of national laboratories (INL, ORNL, and ANL), subcontractors, and universities, which, in concert with the national laboratories, perform R\&D support activities. ART defines the technical work scope, deliverables, reporting, schedules, earned-value performance, milestone status performance, and qualityassurance requirements for these efforts. ART ensures the necessary MPOs, inter-entity work orders (IEWOs), and subcontracts are in place to formally communicate and obtain agreement on work scope definition, requirements, expectations, schedules, and deliverables and to provide the mechanism to fund the performing organizations in their support of R\&D activities. ART also fosters and leverages advanced-reactor technology R\&D across the international community through international collaborations.

The DOE-NE ART Program integrates the following major program elements, comprising three reactor campaigns, three technology $\mathrm{R} \& \mathrm{D}$ areas, international collaborations, and regulatory support. Specifically, the DOE-NE ART Program consists of:

- Gas-Cooled Reactors (GCRs) Campaign-research, develop, demonstrate, and qualify advanced technologies and design methods for high-temperature gas-cooled reactors, including tristructural isotropic (TRISO) fuel, and advanced materials and design methods

- Fast Reactors (FRs) Campaign - enable advanced fast-reactor technologies for closed fuel cycle and power production applications by significantly improving system performance

- Molten Salt Reactors (MSRs) Campaign — evaluate and develop MSR technology and serve as an advocate for the establishment of the United States (U.S.) MSR industry

- Advanced Materials (AMs) Development (technology area cross-cuts GCR, FR and MSR Campaigns) - conduct R\&D activities in the areas of high-temperature materials, graphite, and structural alloys for fast-reactor and molten-salt applications to significantly improve the efficiency, safety, performance, and economics of advanced-reactor systems.

- Energy Conversion (EC) (INL has no work scope within this technology area) — provide solutions to convert the heat from an advanced reactor to useful products that support commercial application of the reactor designs 


\begin{tabular}{|c|lll|}
\hline $\begin{array}{c}\text { ADVANCED REACTOR TECHNOLOGIES } \\
\text { PROGRAM MANAGEMENT PLAN }\end{array}$ & Revision: & PLN-2494 & \\
& Effective Date: & $02 / 07 / 2019$ & Page: 2 of 43 \\
\hline
\end{tabular}

- Microreactors (MRs) - support the development of small reactors for non-traditional applications, including remote terrestrial locations and space

- Generation IV International Forum (GIF) — foster and leverage advanced reactor technology R\&D across the international community

- Regulatory Support (RS) — NRC regulatory framework development and implementation.

ART serves as the lead laboratory for the GCR Campaign, RS, MR, and GIF. It also manages work scope performed at INL in support of advanced reactor technology R\&D led by other national laboratories. Multiple INL facilities and organizations are involved with the R\&D work conducted at INL, including the Advanced Test Reactor (ATR), Materials and Fuels Complex (MFC), and specialized laboratories within both the Nuclear Science and Technology (NS\&T) and the Energy and Environmental Science and Technology directorates.

As part of its lead-laboratory responsibility, ART integrates the following four major GCR Campaign elements and regulatory support to support the NGNP, as outlined in the Energy Policy Act of $2005^{1}$ :

- Fuel Development and Qualification: nuclear fuel development, characterization, and qualification

- High-temperature Materials: materials selection, development, testing, and qualification

- Graphite Development and Qualification: source selection, development, testing, and qualification

- Design Methods and Validation: reactor and balance-of-plant design, engineering, safety analysis, verification, and validation

- Regulatory Support: NRC regulatory framework development and implementation.

A technical program plan is in place for each of the major GCR R\&D elements (fuel development and qualification ${ }^{2}$, high-temperature materials, ${ }^{3}$ graphite, ${ }^{4}$ and design methods and validation $)^{5}$ under the ART, and this plan will be updated as necessary to serve as guidance for budgeting, scheduling, and executing the R\&D activities needed to support the licensing, engineering, and designing of a GCR. The ART director works with ART deputy director, ART project managers, technical leads, the licensing director, and quality-assurance (QA) engineer to integrate and ensure all requirements are well-defined, understood, and documented. The ART deputy director works with ART project managers, technical leads, and program support staff to ensure effective annual planning and execution of work and oversee the assignment of appropriate resources to meet the R\&D needs of ART program.

ART has assigned technical leads to the various R\&D areas. Technical leads ensure ART program needs are met for their assigned technical areas, to integrate and translate project requirements into technical plans, and to serve as work-package managers (WPMs), establishing and managing scope, schedule, and costs.

ART manages projects using standard project-management principles that include defining a work breakdown structure, establishing performance baselines (scope, schedule, and budget), measuring baseline performance, executing baseline-change control, and reporting performance status. In addition to using INL work and project-management procedures, ART has developed and implemented a QA program plan, ${ }^{6}$ data-management plan, ${ }^{7}$ and training plan $^{9}$ to govern how ART program activities are conducted. 


\begin{tabular}{|c|c|c|c|}
\hline $\begin{array}{l}\text { ADVANCED REACTOR TECHNOLOGIES } \\
\text { PROGRAM MANAGEMENT PLAN }\end{array}$ & $\begin{array}{l}\text { Identifier: } \\
\text { Revision: } \\
\text { Effective Date: }\end{array}$ & $\begin{array}{l}\text { PLN-2494 } \\
17 \\
02 / 07 / 2019\end{array}$ & Page: 3 of 43 \\
\hline
\end{tabular}

\section{WORK SCOPE}

The following sections describe the ART program elements identified in Section 1.

\subsection{Fuel Development and Qualification}

\subsubsection{Tristructural Isotropic Fuels}

TRISO fuel development and qualification R\&D consists of seven experiments that will be assembled, irradiated, examined, and tested to provide a baseline fuel-form qualification data set to support the licensing and operation of a high-temperature gas-cooled reactor (HTGR). The seven irradiation experiments, designated as Advanced Gas Reactor (AGR)-1 through AGR-7, have been defined to provide the necessary data and sample materials for post-irradiation examination (PIE). The purposes of the experiments are as follows:

- AGR-1: Early laboratory-scale fuel capsule shakedown

- AGR-2: Large-scale coated-fuel performance demonstration

- AGR-3/4: Designed-to-fail (DTF) fuel to determine fission-product retention behavior

- AGR-5/6/7: Fuel qualification proof and fuel performance margin testing.

The AGR Fuel Development and Qualification program has taken lessons learned from past U.S. fuel experience in the New Production Reactor (NPR) and DOE HTGR Programs, recommendations from international coated-particle fuel experts, and a historical review of the successful coated-particle fuel development program based on existing German technology to establish its initial scope and direction.

The Fuel Development and Qualification Control Account includes the following seven work packages (WPs):

- Fuel Planning and Reporting

- Fabrication

- Irradiation

- Post-irradiation Examination

- Fuel-performance Modeling

- Fuel Data Management and Analysis

- $\quad$ AGR Fuel Licensing Support.

These WPs are integral to the AGR Fuel Development and Qualification Program established by DOE in late 2002. The AGR Fuel Development and Qualification Program has overall goals to:

- Provide a baseline fuel-qualification data set to support the licensing and operation of an HTGR demonstration reactor. Gas-reactor fuel-performance demonstration and qualification comprises the longest duration R\&D task for determining HTGR feasibility. The baseline fuel form is to be demonstrated and qualified for a peak time-averaged fuel centerline temperature of $1,250^{\circ} \mathrm{C}$.

- Support near-term deployment of an HTGR by reducing market-entry risks posed by technical uncertainties associated with fuel production and qualification.

- Use international collaboration mechanisms to extend the value of DOE resources. 


\begin{tabular}{|c|lll|}
\hline $\begin{array}{c}\text { ADVANCED REACTOR TECHNOLOGIES } \\
\text { PROGRAM MANAGEMENT PLAN }\end{array}$ & Revision: & PLN-2494 & \\
& Effective Date: & $02 / 07 / 2019$ & Page: 4 of 43 \\
\hline
\end{tabular}

PLN-3636, "Technical Program Plan for the INL Advanced Reactor Technologies Technology Development Office/Advanced Gas Reactor Fuel Development and Qualification Program,"2 details fuel development and qualification plans and strategies.

\subsubsection{Fuel Planning and Reporting}

Planning activities within the Fuel Development and Qualification Program include development and maintenance of the program lifecycle baseline, annual execution-year budget planning, management and control of the baseline budget, and preparation of the 5-year budget plan.

Reporting activities include monthly reporting of accomplishments, cost and schedule performance, and issues through INL reports and the Project Information Collection System: Nuclear Energy (PICS:NE) input.

Other activities included within this work package include the QA support needed to comply with the ART QA requirements, technical support provided by consultants hired by the program for advice and recommendations as the Technical Coordination Team.

\subsubsection{Fabrication}

Fuel-fabrication activities will produce coated-particle fuel that meets fuel-performance specifications and will include process development for kernels, coatings, and compacting; quality-control method development; scale-up analyses; and process documentation needed for technology transfer. The baseline fuel kernel for the HTGR is low-enriched uranium oxycarbide (UCO) for the prismatic-block reactor version of the HTGR and low-enriched $\mathrm{UO}_{2}$ for the pebble-bed version of the HTGR.

The fuel development and qualification path judged to be the lowest risk to successful fuel qualification for both $\mathrm{UCO}$ and $\mathrm{UO}_{2}$ TRISO fuel is the production of coatings on kernels using technology similar to that applied by German researchers for Arbeitsgemeinschaft Versuchsreaktor and Thorium Hochtemperatur Reaktor fuel development and qualification. The AGR Fuel Development and Qualification Program's coating-development activities have successfully reproduced the coatings based on the German technology at laboratory and production scale. In the AGR-1 experiment, the AGR Fuel Development and Qualification Program irradiated four coated-particle variants, each with slightly different coatings, yet still produced within the acceptable process phase space. This has increased confidence in establishing an acceptable fuel, provided important irradiation-performance feedback to the fabrication process, and decreased the technical risk associated with coating early in the program before fabrication of qualification fuel using production-scale equipment (AGR-5/6/7 experiments).

ART worked with the BWX Technologies Nuclear Operations Group, Inc., to scale coating activities from laboratory to production scale. The fuel (both $\mathrm{UCO}$ and $\mathrm{UO}_{2}$ ) from these efforts was irradiated in the AGR-2 test train in the ATR. The primary purpose of these activities was to demonstrate that high-quality fuel can be manufactured using production-scale equipment and to demonstrate acceptable performance in-reactor and under accident conditions. Upon successful completion of the AGR Fuel Development and Qualification program, the fuel-manufacturing technology will be available to the private sector for use in providing fuel to the next generation of HTGRs.

The AGR-3/4 experiments were performed jointly and were designed to provide fission-product transport and source term data from UCO fuel particles. These experiments included 20 DTF fuel particles in each compact, intended to purposely fail during irradiation to generate fission products within the experiment and components. In addition, a moisture- and impurities-ingress test was performed as a part of these experiments to study the influence of impurities in helium on fuel performance and fissionproduct release. 


\begin{tabular}{|c|lll|}
\hline $\begin{array}{c}\text { ADVANCED REACTOR TECHNOLOGIES } \\
\text { PROGRAM MANAGEMENT PLAN }\end{array}$ & $\begin{array}{lll}\text { Revision: } \\
\text { Effective Date: }\end{array}$ & $\begin{array}{l}\text { PLN-2494 } \\
\text { PAT/2019 }\end{array}$ & Page: 5 of 43 \\
\hline
\end{tabular}

The AGR-5/6/7 experiments are last in the series and will be used to validate and qualify the preferred fuel type for the HTGR. These experiments will include fuel, fabricated at production scale, to demonstrate the capability of a domestic supplier to produce the needed quantity of fuel particles for the first core of an HTGR within the desired timeframe. Additional moisture and air impurities testing will also be performed as a part of these experiments.

\subsubsection{Irradiation}

Fuel and material irradiation activities will provide data on fuel performance during irradiation as necessary to:

- Support fuel process development

- Qualify a fuel design and fabrication process for normal operating conditions

- Support development and validation of fuel-performance and fission-product-transport models and codes

- Provide irradiated fuel and materials, as necessary, for PIE and safety testing.

The seven irradiation experiments, designated as AGR-1 through AGR-7, have been defined to provide the necessary data and sample materials for PIE. The purposes of the experiments are as follows:

- AGR-1: Early laboratory-scale fuel capsule shakedown

- AGR-2: Large-scale coated fuel performance demonstration

- AGR-3/4: DTF fuel to determine fission product retention behavior

- AGR-5/6/7: Fuel qualification proof and fuel performance margin testing.

Irradiation testing of coated-particle fuels occurred routinely in the United States from the 1960s through the early 1990s. Material test reactors have continued operation, and both INL and ORNL have personnel experienced in all aspects of irradiation test train design, assembly, and monitoring. INL and ORNL were both involved in irradiation testing of NPR modular HTGR fuel in the early 1990s. The ATR at INL and High Flux Isotope Reactor (HFIR) at ORNL are both capable of irradiation testing of AGR fuels, although HFIR cannot accommodate testing of full-size (60-mm diameter) pebbles. ATR was selected in large part because of the availability of a reactor irradiation location having a very close match to the nominal gas-reactor spectrum, resulting in an excellent approximation of HTGR burnup and fast fluence.

The temperatures of the test specimens are carefully monitored and controlled during irradiation. Sweep gases flowing past the fuel specimens are carefully monitored for fission-product gases to provide an indication of fuel conditions. Fission-gas detectors, used to monitor the test-train capsules on a near real-time basis, are capable of detecting a single fuel-particle failure in any of the capsules in the test train. Thus, researchers will know if and when fuel particles start to breach during the irradiation.

\subsubsection{Post-Irradiation Examination}

PIE activities, including safety testing, are designed to measure the performance of AGR fuel under normal operating and accident conditions. These activities support the fuel manufacturing effort by providing feedback on the performance of kernels, coatings, and compacts. Data from PIE and safety testing will supplement the in-reactor measurements (primarily the ratio of fission-gas release rates to birth rate) as necessary, to demonstrate compliance with fuel-performance requirements and support the development and validation of computer codes. It will also contribute significantly to the technical basis of the licensee's fuel qualification submittal to the NRC to obtain an operating license for the first HTGR. 


\begin{tabular}{|c|c|c|c|}
\hline $\begin{array}{l}\text { ADVANCED REACTOR TECHNOLOGIES } \\
\text { PROGRAM MANAGEMENT PLAN }\end{array}$ & $\begin{array}{l}\text { Identifier: } \\
\text { Revision: } \\
\text { Effective Date: }\end{array}$ & $\begin{array}{l}\text { PLN-2494 } \\
17 \\
02 / 07 / 2019\end{array}$ & Page: 6 of 43 \\
\hline
\end{tabular}

PIE and safety testing will be performed on each test train after it is removed from the ATR following irradiation. A test plan, detailing the planned PIE and safety-testing activities on each of the AGR test trains will be developed. The major goals of PIE and safety-testing activities are to:

- Collect relevant fuel PIE and safety-testing data to confirm normal operational performance during irradiation, modeling needs, and behavior under accident conditions as a function of temperature, burnup, and fast fluence

- Collaborate with other DOE and international programs to the maximum extent possible to resolve key design and data needs, minimize duplication of effort, and leverage available funding.

HTR fuel has been tested and examined at ORNL since the 1960s, and the hot cells still have a full range of capabilities to conduct examinations. In addition, the hot cells at INL have been used to examine a wide variety of irradiated fuels for many years, including TRISO coated gas-reactor target particles in the NPR modular HTGR program. The hot cells at both ORNL and INL are operating and functional today. If new or additional examinations are required for the AGR, both ORNL and INL have competent staff to design and build the required equipment and develop the examination protocols.

Once irradiation is completed and an appropriate cooldown period has passed, the test trains are removed from the ATR canal and transferred to MFC, specifically to the Hot Fuels Examination Facility (HFEF) main cell, where they are disassembled for PIE and tested in the main cell, the Analytical Laboratory hot cells, and the Electron Microscopy Laboratory. PIE includes visual examination, component metrology, fuel-specimen deconsolidation, leach-burn-leach, chemical analysis, metallography, scanning electron microscopy of the fuel particles, and simulated exposure of fuel specimens to reactor-accident-temperature conditions in a high-temperature furnace. The degradation of the fuel at potential accident-condition temperatures $\left(1600-1800^{\circ} \mathrm{C}\right)$ is evaluated based on measurements of the fission products and gases that evolve from the heated fuel specimens. After the safety tests are completed, metallography and scanning electron microscopy are performed on the heated fuel specimens.

A number of irradiated fuel compacts from each experiment will be shipped to ORNL for PIE and safety testing. PIE and safety testing performed at ORNL include additional in-depth investigation and analysis of fuel-particle behavior and complementary PIE and testing of INL performed PIE and safety testing.

\subsubsection{Fuel-performance Modeling}

Fuel-performance modeling activities address the structural, thermal, and chemical processes that can lead to coated-particle fuel failures. The model addresses the release of fission products from the fuel particle and fission-product chemical interaction with the coatings, which can lead to degradation of the coated particle's fuel properties. Fuel performance models are used to:

- Assist in the development of candidate coated-particle fuel designs

- Predict the performance of coated-particle fuel during irradiation testing and post-irradiation safety or heat-up testing

- Calculate fuel performance for HTGR core designs during normal operation and hypothetical accident conditions.

Many attempts have been made to model the performance of coated-particle fuels. However, efforts have not resulted in a comprehensive model capable of predicting fuel performance with sufficient 


\begin{tabular}{|c|lll|}
\hline $\begin{array}{c}\text { ADVANCED REACTOR TECHNOLOGIES } \\
\text { PROGRAM MANAGEMENT PLAN }\end{array}$ & $\begin{array}{lll}\text { Revision: } \\
\text { Effective Date: }\end{array}$ & $\begin{array}{l}\text { PLN-2494 } \\
\text { PAT/2019 }\end{array}$ & Page: 7 of 43 \\
\hline
\end{tabular}

accuracy to directly facilitate fuel design or replace the need for comprehensive test data in a licensing application. Thus, the goals for fuel performance modeling activities are to:

- Develop more first-principles-based fuel performance models of coated-particle fuel (either with $\mathrm{UCO}$ or $\mathrm{UO}_{2}$ ) that can:

- Guide current and future particle designs

- Assist in irradiation and safety experiment planning

- Predict observed fuel failures

- Allow more accurate interpolation of fuel performance inside the performance envelope needed for core design assessments, and modest extrapolation of fuel performance outside the existing performance envelope, when required.

- Develop a prioritized list of material properties and constitutive relations needed for accurate modeling of coated-particle fuel under normal and off-normal conditions

- Develop advanced models that take advantage of new models and methods

- Benchmark these models/codes against U.S. and international irradiation and safety experiments, where possible.

Fission product transport activities, including source term modeling, address the transport of fission products produced within the coated-particle fuel to the exclusion-area boundary that will provide a technical basis for source terms under normal and accident conditions. The technical basis will be codified in design methods (computer models) and validated by experimental data, as necessary, to support HTGR design and licensing.

A major activity associated with TRISO coated-particle fuel is qualification of the source term, both from a technical standpoint and within the licensing framework being established with the NRC. Data are needed to qualify the mechanistic source term and the associated methods to be used in the HTGR safety analysis and licensing submittal. Thus, in parallel with the fuel-qualification-related irradiations, two experiments (AGR-3/4) are dedicated to studying the behavior of fission products released from DTF fuel and the holdup in the fuel compact matrix and graphite block-both important elements in defining a mechanistic source term for the HTGR. Thus, the fission-product retentiveness of this new generation of graphitic materials must be established and qualified.

Irradiation experiment AGR-7, and subsequent safety testing and PIE are dedicated to fuel performance and validation of fission-product transport models, important for fuel-performance-related core-design activities and qualification of the mechanistic source term. Additionally, a potential series of out-of-pile experiments and helium loops are included in the AGR Fuel Development and Qualification program to measure fission-product plate out on primary system components under normal operation and resuspension (or liftoff) under accident conditions.

\subsubsection{Fuel Data Management and Analysis}

Fuel data management and analysis activities include data collection, qualification, and analysis. The data are stored in a readily accessible electronic form, categorized to assure the correct data are used and controlled to prevent data corruption or inadvertent changes. These requirements are met by using the Nuclear Data Management and Analysis System (NDMAS). NDMAS:

- Supports data qualification

- Stores data in a controlled and secure electronic environment

- Identifies the qualification status of data 


\begin{tabular}{|c|lll|}
\hline $\begin{array}{c}\text { ADVANCED REACTOR TECHNOLOGIES } \\
\text { PROGRAM MANAGEMENT PLAN }\end{array}$ & $\begin{array}{lll}\text { Revision: } \\
\text { Effective Date: }\end{array}$ & $\begin{array}{l}\text { PLN-2494 } \\
\text { PAT/2019 }\end{array}$ & Page: 8 of 43 \\
\hline
\end{tabular}

- Provides data analysis and modeling

- Makes data available for use by ART program.

NDMAS is web-based, so ART program members can access the system and review the data, obtain analysis results (including statistics and graphics), and download data for advanced analysis. By performing these roles, NDMAS ensures the correct data are used by ART program and that data of known quality will be available to support licensing in the future. Furthermore, NDMAS maintains documentation of QA plans and procedures that were followed during irradiation and PIE data collection activities. This ensures that evidence of compliance with American Society of Mechanical Engineers (ASME) Nuclear Quality Assurance (NQA)-1 2008/1a-2009, "Quality Assurance Requirements for Nuclear Facility Applications," will be available for future licensing efforts.

\subsubsection{AGR Fuel Licensing Support}

The scope of this work package is to support development of the content of a licensing topical report addressing the development of the TRISO particle-fuel form based on completed AGR Program technical work. It is expected that industry stakeholders planning to utilize this fuel form (modular HTGRs and FHRs) will finalize the report's content and submit it to the NRC for review and approval. The final topical report submitted to the NRC is expected to address the following topics:

- TRISO UCO fuel design characteristics and rationales

- TRISO UCO fuel product specifications

- Description of relevant portions of the fuel-fabrication process

- Statistical QA and quality-control methods applied that assure specifications are met.

\subsection{Advanced Materials Development}

Work in the Advanced Materials Development technology area supports DOE-NE's mission in advancing nuclear power to meet the nation's energy, environmental, and energy security needs. A variety of R\&D activities in the areas of high-temperature materials, graphite, and structural alloys for fast-reactor and molten-salt applications are being conducted to significantly improve the efficiency, safety, performance, and economics of advanced-reactor systems. In addition to the operating-temperature range, the selection of construction materials for an advanced reactor is critically dependent on the coolant system because of material compatibility and mass-transfer issues, particularly for the lengthy design lifetime desired to reduce annualized capital costs. Therefore, different construction materials are often required for different advanced-reactor systems. QA of data plays a vital role in establishing confidence in the R\&D results developed by the Advanced Materials program. Data are generated to the ASME NQA-1 2008/1a-2009 quality level or its equivalent.

\subsubsection{High Temperature Materials}

The High Temperature Materials Program supports the HTGR design and licensing process. The thermal, environmental, and service-life conditions of the HTGR will make selection and qualification of high-temperature materials a significant challenge; thus, new materials and approaches may be required.

Objectives of the High Temperature Materials Program include the following:

- Expansion of the materials and design ranges allowed by the ASME Code for HTGR applications

- Characterization of significant in-service degradation mechanisms, together with definition and development of inspection needs and associated procedures 


\begin{tabular}{|c|c|c|c|}
\hline $\begin{array}{l}\text { ADVANCED REACTOR TECHNOLOGIES } \\
\text { PROGRAM MANAGEMENT PLAN }\end{array}$ & $\begin{array}{l}\text { Identifier: } \\
\text { Revision: } \\
\text { Effective Date: }\end{array}$ & $\begin{array}{l}\text { PLN-2494 } \\
17 \\
02 / 07 / 2019\end{array}$ & Page: 9 of 43 \\
\hline
\end{tabular}

- Development of methods and structural data to address high-temperature design methods and materials issues identified by the regulatory body, as well as the Advisory Committee on Reactor Safeguards, in order to preempt hurdles in the HTGR licensing process

- Support of selected materials-related university R\&D activities that would directly benefit the HTGR

- Support of international materials related collaboration activities through the DOE-sponsored GIF Materials Project Management Board.

\subsubsection{High Temperature Materials Research}

The R\&D elements of the High Temperature Materials (HTM) Program are described in the following paragraphs. Major activities associated with HTM research address the methods that will be used to characterize properties to support the selection of heat-exchanger materials and aid in the design of the reactor/hydrogen production interface. Significant progress has been made in the past five years on the development of new design rules, analysis methods, and data for a Code Case for incorporation of Alloy 617 into the ASME Boiler and Pressure Vessel Code. These activities include:

- Experimental characterization of physical and mechanical properties of Alloy 617 to support the development of ASME Code allowables, using the methods specified in Code Sections II and III

- Critical assessment of design parameters, such as allowable levels of cold work and any reduction in properties associated with weldments.

Additional details for the Alloy 617 materials R\&D are provided in PLN-2804, "Next Generation Nuclear Plant Steam Generator and Intermediate Heat Exchanger Materials Research and Development Plan."3

Major testing activities for Alloy 617 have been completed. The focus of current efforts is on balloting the Code Case and the preparation of the background documents for evaluations by ASME Code committees. The Alloy 617 Code Case has been fully approved for nuclear components up to $425^{\circ} \mathrm{C}$. The high-temperature Code Case that will allow fabrication of components from Alloy 617 up to $950^{\circ} \mathrm{C}$ for up to 100,000 hours is in the ballot process.

Near-term activities associated with high-temperature-materials research involve the extension of the temperature and time for Alloy $800 \mathrm{H}$ in support of HTGR steam-generator design. Additional details for the Alloy $800 \mathrm{H}$ materials R\&D are provided in PLN-2804.

In the longer term, the HTM Program will address cross-cutting issues of materials behavior during extended service beyond the scope of the current Code and high-temperature design and materials issues identified by the regulatory body in support of the licensing process. These include notch effects on creep and rupture, crack growth, and fracture mechanics under prototypical HTGR heat-exchanger and steamgenerator environments. It is also critical to understand at a fundamental level the relationship between complex multiaxial component loading and metallurgical long-term integrity of welded construction, and development of validated weldment design rules and analysis methods is needed to address the concern.

\subsubsection{Graphite Research and Development}

The Graphite Program supports the HTR design and licensing process. The thermal, environmental, and service-life conditions within a graphite-core reactor design make selection and qualification of the graphite materials a significant challenge; thus, new graphite sources and approaches may be required. In addition, due to the geologic nature of graphite source materials, small but significant variations within these raw materials exacerbate difficulties in qualification of a single graphite grade. To address these additional complications, the Graphite Program includes graphite grades that span the range of possible attributes affecting the performance of graphite components within these HTRs and, thus, provide data and information to accurately predict and model irradiated-graphite behavior. 


\begin{tabular}{|c|c|c|c|}
\hline $\begin{array}{l}\text { ADVANCED REACTOR TECHNOLOGIES } \\
\text { PROGRAM MANAGEMENT PLAN }\end{array}$ & $\begin{array}{l}\text { Identifier: } \\
\text { Revision: } \\
\text { Effective Date: }\end{array}$ & $\begin{array}{l}\text { PLN-2494 } \\
17 \\
02 / 07 / 2019\end{array}$ & Page: 10 of 43 \\
\hline
\end{tabular}

Objectives of the Graphite Program include the following:

- Expanding ASME codes and ASTM international standards for graphite nuclear components

- Developing and qualifying graphite sources

- Developing irradiation performance of a variety of nuclear graphite grades

- Defining inspection needs and developing associated procedures

- Supporting selected graphite-related university R\&D activities that would directly benefit the HTR through fundamental behavior studies of underlying irradiation mechanisms

- Supporting international graphite-related collaboration activities (for qualification and fundamentalbehavior studies) through the DOE-sponsored GIF Materials and Components Project Management Board.

\subsubsection{Graphite Development and Qualification Research}

To provide the essential graphite materials R\&D required to support design and licensing data for current and future graphite-core reactor designs, three general areas of nuclear graphite $\mathrm{R} \& \mathrm{D}$ have been established. Detailed graphite R\&D activities are specified in PLN-2497, "Graphite Technology Development Plan."

\subsubsection{Advanced Graphite Creep Experiment Design}

The Advanced Graphite Creep (AGC) Experiment encompasses the core of the irradiation materialproperty activities. The AGC Experiment irradiation test series is designed to determine irradiation property changes and the life-limiting creep rates for moderate doses and higher temperatures in leading graphite types that will be used in graphite-reactor design. Six graphite-material irradiations will be completed to obtain irradiation-creep data for new nuclear-grade graphites being considered for use in a graphite-core reactor. The AGC Experiment encompasses three general areas of activity: (1) design and fabrication of the six AGC test trains; (2) irradiation of each AGC test train; and (3) pre- and post- irradiation examination and testing of the AGC graphite specimens.

The Department of Energy originally decided to concentrate on a prismatic very-high-temperature reactor design which required a graphite $\mathrm{R} \& \mathrm{D}$ irradiation program consisting of high-temperature, lowdose irradiations. However, current commercial-reactor vendor designers have expressed interest in other HTR designs, such as molten-salt and gas-cooled pebble bed, which require a graphite R\&D irradiation program concentrating on low-temperature, high-dose irradiations.

Based on the change in priorities described above, DOE has decided to repurpose the AGC-5 and AGC-6 experiments to support the current interest in reactor designs requiring data from low-temperature, high-dose graphite irradiations.

Repurposing of the AGC-5 test train consists of re-irradiating graphite samples previously irradiated in the AGC-2 experiment and will be designated as High Dose Graphite (HDG)-1. AGC-2 was irradiated in the ATR South Flux Trap at $600^{\circ} \mathrm{C}$ during cycles 149A, 149B, 150B, and 151B and received a maximum dose of $3.8 \mathrm{dpa}$.

HDG-1 will be irradiated in the ATR East Flux Trap at $600^{\circ} \mathrm{C}$ upon completion of the AGC-4 irradiation. The graphite experiments receive approximately $1 \mathrm{dpa}$ per cycle (maximum) in ATR. The goal will be to irradiate HDG-1 for 11 cycles, bringing the total dose of the previously irradiated AGC-2 samples up to $15 \mathrm{dpa}$ (maximum). HDG-2 will re-irradiate samples previously contained within the AGC3 and AGC-4 test trains. 


\begin{tabular}{|c|lll|}
\hline $\begin{array}{c}\text { ADVANCED REACTOR TECHNOLOGIES } \\
\text { PROGRAM MANAGEMENT PLAN }\end{array}$ & Identifier: & PLN-2494 & \\
& Revision: & 17 & \\
& Effective Date: & $02 / 07 / 2019$ & Page: 11 of 43 \\
\hline
\end{tabular}

A high-temperature vessel (HTV) irradiation experiment was also conducted to provide very hightemperature irradiation-damage data and serve as a dimensional change experiment to determine when turnaround is expected to occur in all AGC/HDG graphite grades. The AGC/HDG test series is designed to be conducted at the following dose and target temperatures:

- AGC-1: 3-6 dpa at $600^{\circ} \mathrm{C}$

- AGC-2: 1-4 dpa at $600^{\circ} \mathrm{C}$

- AGC-3: 0.5-3 dpa at $800^{\circ} \mathrm{C}$

- AGC-4: 3-6 dpa at $800^{\circ} \mathrm{C}$

- HDG-1: up to $15 \mathrm{dpa}$ at $600^{\circ} \mathrm{C}$

- HDG-2: up to $20 \mathrm{dpa}$ at $800^{\circ} \mathrm{C}$

- HTV: 2-4 dpa at $1400^{\circ} \mathrm{C}$.

\subsubsection{Graphite Material Properties}

Graphite material-properties activities focus on graphite characterization, data analysis, behavior determination, and performance prediction for unirradiated and irradiated candidate grades of graphite in support of codification, design, and licensing of a graphite-core reactor. Material properties covers four primary areas: (1) development of an unirradiated baseline (virgin) material-property database;

(2) analysis of all data from irradiated and unirradiated testing programs; (3) collaborative research with university and international graphite researchers; and (4) prediction of graphite performance.

The baseline data include unirradiated data for all five major graphite grades selected for the ART Graphite Development and Qualification Program. To assure statistical accuracy, three billets for each graphite grade (each a different billet selected from separate fabrication batches) are tested for the Baseline Program. Historically, it has taken approximately 12 months to perform baseline testing on a full-graphite billet.

Performance-model studies, such as fracture toughness, oxidation-model development, mechanical strength, and irradiation-damage mechanisms, have been initiated. The models will be further developed and refined as the unirradiated and irradiated data (and results from fundamental studies) become available. Validated behavior models will then be used to predict graphite component performance in graphite core reactors for eventual ASME codification of graphite for nuclear applications.

\subsubsection{Graphite Data Management and Analysis}

The graphite data-management and analysis activities focus on qualifying the graphite data generated, storing the data in a readily accessible electronic form, categorizing the data to assure the correct data are used and shared with appropriate collaborators, and controlling the data within storage to prevent data corruption or inadvertent changes. These requirements are met using the NDMAS system. NDMAS maintains documentation of QA plans and procedures that were followed during irradiation and PIE data-collection activities. This ensures that evidence of compliance with ASME NQA-1 2008/1a-2009 will be available for future licensing efforts. 


\begin{tabular}{|c|lll|}
\hline $\begin{array}{c}\text { ADVANCED REACTOR TECHNOLOGIES } \\
\text { PROGRAM MANAGEMENT PLAN }\end{array}$ & Identifier: & PLN-2494 & \\
& Revision: & 17 & \\
& Effective Date: & $02 / 07 / 2019$ & Page: 12 of 43 \\
\hline
\end{tabular}

\subsection{Design Methods and Validation}

The development, design, permitting, and construction of an HTR requires multiple and varied analyses and computational methods. The gas-cooled thermal reactors built and operated in the United States and elsewhere to-date are characterized by sustained operations at conditions that have substantial design and safety margins. The margins were designed to be large because the legacy analysis tools were not capable of calculating important local limiting parameters with sufficient accuracy to reduce the safety margins.

The Design Methods and Validation Program provides advanced tools for HTGR design and analysis activities. Most of these tools are already available and consist of a mixture of commercial software and software written at the national laboratories. Only limited tool development is necessary for HTR methods. The Design Methods and Validation Control Account consists of two WPs:

- Methods Experimental Validation

- Methods Core Simulation.

Activities focus on developing and benchmarking state-of-the-art analysis tools that enable vendor, NRC, and DOE analysts to model accurately the behaviors of an HTR. Software requirements are determined by evaluating NRC Regulatory Guide 1.203, "Transient and Accident Analysis Methods."11 Specific implementation of those requirements is defined in quality-level determinations and/or software management plans.

Products that are provided by the Design Methods and Validation Program include software tools and experiments for the validation of these tools to allow HTGR operational and licensing requirements to be calculated. These tools are used to analyze normal, off-normal, and accident conditions. The advantages of advanced analysis tools over older legacy analysis tools are

- Reduced design uncertainty and risk. The localized conditions can be calculated with a known uncertainty.

- Reduced design iterations and design costs. The plant designers can more rapidly converge on their desired design configuration with less uncertainty.

- Accelerated licensing process. The process of prescribing arbitrary safety factors is transformed to a process of using known quantities with quantified uncertainties.

- Capability of quantifying the safety and operational margins to optimal values for maximum outlet temperatures and maximum operational efficiencies.

Most of the Design Methods and Validation Program is focused on software verification and validation $(\mathrm{V} \& \mathrm{~V})$. Once $\mathrm{V} \& \mathrm{~V}$ of the software is completed, the methods-generated tools can be used by vendors and will be available for use by DOE and NRC. PLN-2498, "Next Generation Nuclear Plant Methods Technical Program Plan," details Design Methods and Validation program roles, methods, approaches, and planned R\&D activities. The R\&D elements of the Design Methods and Validation program are described in the following subsections.

\subsubsection{Methods Experimental Validation}

The objective of methods experimental validation is to generate qualified data and standards for $\mathrm{V} \& \mathrm{~V}$ of HTR thermal-fluid and plant-simulation needs. These needs are determined by the anticipated operational and accident envelopes of the system, which are identified and prioritized using the phenomena identification and ranking tables (PIRTs). The calculational envelope of thermal-fluid software must either match or encompass system operational and accident envelopes. This is 


\begin{tabular}{|c|c|c|c|}
\hline $\begin{array}{l}\text { ADVANCED REACTOR TECHNOLOGIES } \\
\text { PROGRAM MANAGEMENT PLAN }\end{array}$ & $\begin{array}{l}\text { Identifier: } \\
\text { Revision: } \\
\text { Effective Date: }\end{array}$ & $\begin{array}{l}\text { PLN-2494 } \\
17 \\
02 / 07 / 2019\end{array}$ & Page: 13 of 43 \\
\hline
\end{tabular}

accomplished by defining the physics in software. The software physics models must properly calculate the key phenomena identified through the PIRT process, as determined by V\&V. A high-fidelity data matrix and/or exact analytical-solution set exist to provide benchmarks for computational results. The ASME V\&V 30 Committee will seek acceptances as a standard, specifying the applicable software validation matrix, experiment scaling and design procedures, and methodology to ensure that completed validations define a software calculational envelope that encompasses anticipated operating conditions.

The Methods group develops and uses computational methods suitable for performing auditing calculations and other analyses as prescribed by federal agencies such as DOE and NRC. These methods are implemented into HTR systems-analysis codes to simulate and study the complex dynamic behavior of HTRs, particularly those phenomena that impact safety. These methods, including commercial computational fluid dynamics (CFD) and systems-analysis codes, will be validated in the form of standard problems using data from scaled experimental facilities. Planning, preliminary code development, testing against appropriate benchmarks, and scoping studies to support an HTR are performed. Support is provided to the High Temperature Test Facility at Oregon State University in the form of pre- and post-test analyses using CFD and systems-analysis codes, facility-scaling reviews and analysis, and advanced instrumentation recommendations and designs. The behavior of an HTR reactor cavity-cooling system will be examined in experiments and analyses at ANL.

\subsubsection{Methods Core Simulation}

The nuclear physics design of the HTR core requires the use of verified and validated computational methods for the calculation of core-physics parameters. To complete the V\&V of HTR computational methods, it must be proven that the computational methods calculate certain physics parameters within acceptable uncertainty criteria. Therefore, the objective of core simulation is to develop core-physics modules that enable the accurate simulation of pebble-bed and prismatic HTR core steady-state and transients to support safety experiments, fuels testing, and NRC-evaluation model development. These modules include prototypical temperatures, burnups, and fluences for AGR fuel, decay-heat curves and power and temperature profiles for integral experiments, validation against the High Temperature Test Reactor and HTR-10, and simulations of anticipated transients with high fidelity tools for confirmation of vendor/NRC analyses.

\subsubsection{Methods International Collaborations}

\subsubsection{Civil Nuclear Energy Working Group Collaboration with Japan}

Japan and the United States are engaged in the research and development of high-temperature gascooled reactor technology. Each country possesses unique and complementary experimental facilities. Under the Civil Nuclear Energy Working Group collaboration, Japan Atomic Energy Agency and DOE will share simulating codes, experiment facility models, and results, and will engage in joint planning of new experiments using these facilities that will result in a consistent set of data that can be used for HTGR code validation.

\subsubsection{Computational Methods Validation Board}

The GIF Computational Methods Validation Board allows use of experimental data from member countries to validate computational models. Focus areas include core system behavior, CFD, chemistry and transport (graphite oxidation and tritium), and reactor physics. The U.S. benefits from receipt of data from experiments performed by member countries, including the Korean Hybrid Reactor Cavity Cooling System and China's High Temperature Reactor Pebble-bed Module and component tests. The project plan, approved in 2017, defines multiyear activities related to HTR experimental validation with specific work packages in PIRT update and reconciliation, CFD, reactor physics, chemistry and fission-product transport, and systems analysis. 


\begin{tabular}{|c|lll|}
\hline $\begin{array}{c}\text { ADVANCED REACTOR TECHNOLOGIES } \\
\text { PROGRAM MANAGEMENT PLAN }\end{array}$ & Revision: & PLN-2494 & \\
& Effective Date: & $02 / 07 / 2019$ & Page: 14 of 43 \\
\hline
\end{tabular}

\subsection{Licensing}

The mission of Licensing is to work closely with industry, NRC staff, and other potential contributors to identify and resolve key licensing and regulatory issues for advanced-reactor developers, future owner/operators, and other affected industry stakeholders. The goal, or "end state," of the work being performed is establishment of a licensing pathway for non-light-water reactors that is sufficiently robust and well defined that reactor developers, their sponsors, and interested owner/operators can move forward with increased clarity and reasonable assurance of licensing success that, in-turn, leads to commercial deployment. In particular, it is intended that resolution of the key licensing issues addressed by this work does not impact the "critical path" to non-light-water reactor development, demonstration, and commercialization.

When establishing its priorities, Regulatory Development focuses first on those activities that address and resolve challenges that are inclusive of advanced-reactor technology. This identification of priority activities related to regulatory framework development is closely coordinated through interfaces with the DOE ART Program technology campaigns, with industry (e.g., the Nuclear Energy Institute [NEI] and Electric Power Research Institute [EPRI]), and with the NRC's near-term implementation action plans. Activities currently being emphasized include consideration of the following reactor technologies:

- Sodium Fast Reactors

- Lead Fast Reactors

- Gas-cooled Fast Reactors

- Modular High Temperature Gas-cooled Reactors

- Fluoride High Temperature Reactors

- Molten Salt Reactors

- Microreactors

Contingent on available resources, Regulatory Development next focuses on the activities that benefit a specific type or class of advanced technology, with priority given to those technologies being actively supported and advanced within DOE-NE's ART Program.

During FY-19, Regulatory Development will continue to manage the Licensing Modernization Project (LMP), which was initiated in April 2016. The LMP is an industry-led team of licensing and advanced-reactor technology subject-matter experts, prospective advanced-reactor technology license applicants, and a number of current fleet owner/operators that bring important insights and deployment considerations to the overall LMP strategy. The LMP is supported through a cost sharing arrangement with DOE-NE and private industry.

The LMP concept is unique in that, while LMP leadership is provided by a single prospective reactortechnology owner/operator, the efforts of the LMP team are focused on the broad needs of the entire advanced reactor community (e.g., commercial advanced-reactor designers and suppliers, utility owners/operators, regulators, industry advocacy groups, and the public). The expected outcome of the LMP is formal NRC endorsement in 2019 of an industry approach for addressing the following key Commission policy topics:

- Licensing basis event selection

- Use of probabilistic risk assessment approaches in licensing decisions

- Classification of structures, systems, and components 


\begin{tabular}{|c|c|c|c|}
\hline $\begin{array}{l}\text { ADVANCED REACTOR TECHNOLOGIES } \\
\text { PROGRAM MANAGEMENT PLAN }\end{array}$ & $\begin{array}{l}\text { Identifier: } \\
\text { Revision: } \\
\text { Effective Date: }\end{array}$ & $\begin{array}{l}\text { PLN-2494 } \\
17 \\
02 / 07 / 2019\end{array}$ & Page: 15 of 43 \\
\hline
\end{tabular}

- Evaluation of defense-in-depth adequacy.

\subsection{Microreactors}

The Microreactors technology area supports the development of small reactors for non-traditional applications, including remote terrestrial locations and space. Although both areas are led by INL, work scope is only being conducted within Remote Commercial and Defense Applications in FY-19. Department of Defense interests stem from the need for uninterrupted mobile power that is not vulnerable to cybersecurity threats and provides heat and power to enable a variety of operations at remote sites and forward operating bases. Civilian interest is similar in nature (hybrid heat and power at remote locations and mining sites), but with particular emphasis on cost and fuel utilization. Very small modular reactors $(<20 \mathrm{MWe})$ will be designed, developed, and tested to ensure they will meet defense and commercial application needs.

\subsection{Fast Reactor R\&D}

The Fast Reactor (FR) Campaign, led by ANL, performs targeted research to enable commercial deployment of FR technology. It provides the research, development, and demonstration of innovative cost-reduction and performance-enhancement technologies, including system-integration studies to confirm the feasibility and to estimate the benefits of new options. It also clarifies FR licensing criteria and the science-based approach for demonstration of regulatory compliance, building on NRC advancedreactor criteria to support emerging regulatory issues. Finally, the FR campaign serves to develop and sustain domestic infrastructure and the knowledge base for research, development, and demonstration of fast-spectrum systems, including both facility and human resources. The ART supports the FR campaign with materials R\&D.

\subsubsection{Fast-reactor Materials R\&D}

The advanced stainless steel Alloy 709 is being developed to replace Type 316 stainless steel in some sodium-cooled fast-reactor applications. An effort is ongoing to qualify this material for nuclear components under the ASME Code. Testing is underway to characterize the fatigue, creep-fatigue, and creep properties of commercial-scale heats. Near-term activities focus on extended scoping studies to determine the optimal melt practice, rolling schedule, and solution treatment. In the long term, the testing program will lead to sufficient information to develop allowable time-dependent stresses and to define the creep-fatigue interaction diagram.

\subsubsection{Fast-reactor Methods, Modeling and Validation}

INL's effort in this area is devoted to the collaboration with International Atomic Energy Commission on the neutronic aspects of fast reactors of the advanced sodium technological reactor for industrial demonstration (ASTRID) type. Under a bilateral agreement with France, ANL and INL collaborate to support efforts on ASTRID core-design and safety-analysis benchmarks, with emphasis on joint studies of error propagation in safety-analysis and neutronics issues for large cores. The objectives are to improve nuclear data that are relevant to the ASTRID neutronic design; design and analyze integral experiments relevant to ASTRID; and study decoupling characteristics of the ASTRID reactor in order to assess if spatial effects exist that can affect transient scenarios of the reactor.

\subsection{Molten Salt Reactor R\&D}

The Molten Salt Reactor Campaign, led by ORNL, seeks to evaluate and develop MSR technology and serves as an advocacy for the establishment of the U.S. MSR industry. The campaign will identify and address the challenges associated with bringing an MSR industry to the market. Its goal is to develop 


\begin{tabular}{|c|c|c|c|}
\hline $\begin{array}{l}\text { ADVANCED REACTOR TECHNOLOGIES } \\
\text { PROGRAM MANAGEMENT PLAN }\end{array}$ & $\begin{array}{l}\text { Identifier: } \\
\text { Revision: } \\
\text { Effective Date: }\end{array}$ & $\begin{array}{l}\text { PLN-2494 } \\
17 \\
02 / 07 / 2019\end{array}$ & Page: 16 of 43 \\
\hline
\end{tabular}

opportunities to build MSRs within a decade. The ART supports the MSR campaign with coolantchemistry R\&D in FY-19.

Research in this area will evaluate processes and systems that would be used to handle and process salts from salt-fueled reactor concepts, as proposed in various MSR nuclear fuel-recycling schemes. It will attempt to define the requirements and conceptualize processes and systems likely to be considered for waste-stream handling that are consistent with in-situ processing during reactor operation.

\subsection{International Collaborations}

International collaborations are conducted to foster and leverage advanced-reactor technology R\&D across the international community. The Generation International Forum promotes the development of concepts for one or more Generation IV nuclear energy systems that can be licensed, constructed, and operated in a manner that will provide a competitively priced and reliable supply of energy to the country where such systems are deployed while satisfactorily addressing nuclear safety, waste, proliferation, and public perception concerns.

GIF was established in 2001 for the purpose of promoting research and development of Gen-IV reactors through international cooperation. GIF includes 14 member countries. While some members have become inactive, new members have joined and, over time, a more-effective cooperative structure has evolved. Six nuclear systems were selected for collaborative research and development by the member countries.

GIF operates both Policy and Experts Groups, with two members in each group nominated by their respective member countries. The Policy Group governs overall framework and policies. The Experts Group reviews progress of collaborative projects, identifies new directions for research and makes recommendations to the Policy Group. The GIF Secretariat organizes meetings, coordinates communication for GIF activities and status, maintains procedures for key actions, and performs other tasks as directed by the Policy Group.

GIF strategic-planning activities encompass the three themes of 1) technology roadmap update, 2) strategies for strengthening $R \& D$ collaboration, and 3) strategies for strengthening ties with other international organizations.

\section{ART PROGRAM}

\subsection{Organization and Interfaces}

The DOE-NE ART program is managed by three co-national technical directors (NTDs), each overseeing a reactor-technology campaign (i.e., GCR, FR, and MSR) work scope. Additionally, there are four technology area leads (TALs) managing AM, MR, EC and RS, which are not specific to any one reactor technology. All of the reactor campaigns and technology areas conduct work scope at multiple national laboratories. Because each national laboratory manages work to its site specific policies and procedures, this program management plan addresses only the work scope for which ART is responsible (i.e., work scope performed at the INL or via MPOs at another national laboratory).

The intent of ART is to staff ART program with the right people to accomplish the work, regardless of location or affiliation. As appropriate, technology-development and execution activities use facilities and staff from multiple national laboratories-including INL, ORNL, ANL, Pacific Northwest National Laboratory - universities, industrial-alliance partners, consulting organizations, and research groups from cooperating foreign countries. ART also ensures the necessary MPOs, IEWOs, and subcontracts are in place to formally communicate and obtain agreement on work-scope definition, requirements, expectations, schedules, and deliverables and to provide the mechanism to fund the performing 


\begin{tabular}{|c|c|c|c|}
\hline $\begin{array}{l}\text { ADVANCED REACTOR TECHNOLOGIES } \\
\text { PROGRAM MANAGEMENT PLAN }\end{array}$ & $\begin{array}{l}\text { Identifier: } \\
\text { Revision: } \\
\text { Effective Date: }\end{array}$ & $\begin{array}{l}\text { PLN-2494 } \\
17 \\
02 / 07 / 2019\end{array}$ & Page: 17 of 43 \\
\hline
\end{tabular}

organizations in their support of R\&D activities. ART also fosters and leverages advanced-reactor technology R\&D across the international community through international collaborations.

\subsection{Roles, Responsibilities, Accountabilities, and Authorities}

Table 1 provides the roles, responsibilities, accountabilities, and authorities (R2A2s) for the various positions within ART.

Table 1. Summary of ART R2A2s.

\begin{tabular}{|l|l|}
\hline \multicolumn{1}{|c|}{ Position } & \multicolumn{1}{|c|}{ R2A2s } \\
\hline ART Director/ Co-National & Works with DOE-NE program director to develop ART \\
Technical Director & Program direction, priorities, and milestones. \\
Communicates program direction and expectations to ART \\
Deputy Director, project managers, technical leads, and WPMs. \\
Collaborates with other ART NTDs to integrate priorities \\
across reactor campaigns. \\
Integrates priorities within respective reactor campaigns. \\
Allocates funding within respective reactor campaign. \\
& Ensures work performed within respective campaign is \\
& consistent with program objectives and provides benefit. \\
& Participates in program review meetings. \\
& Identifies opportunities for collaboration/leverage across ART \\
& Program. \\
& Communicates performance status and issues to DOE-NE \\
& program director. \\
& Performs final review and approval of Level 1 and 2 milestone \\
deliverables. & Ensures implementation of applicable QA program. \\
& Participates in DOE-NE Nuclear Technology R\&D monthly \\
performance status teleconference. & Participates in DOE-NE ART Program monthly performance \\
& status teleconference. \\
& Provides skilled and qualified resources to perform work scope. \\
Approves integrated priority list input in response to multi-year \\
budget call. \\
Authorizes baseline changes. \\
Provides oversight of international collaborations.
\end{tabular}




\begin{tabular}{|c|c|c|c|}
\hline $\begin{array}{l}\text { ADVANCED REACTOR TECHNOLOGIES } \\
\text { PROGRAM MANAGEMENT PLAN }\end{array}$ & $\begin{array}{l}\text { Identifier: } \\
\text { Revision: } \\
\text { Effective Date: }\end{array}$ & $\begin{array}{l}\text { PLN-2494 } \\
17 \\
02 / 07 / 2019\end{array}$ & Page: 18 of 43 \\
\hline
\end{tabular}

Table 1. (continued).

\begin{tabular}{|c|c|}
\hline Position & $\mathrm{R} 2 \mathrm{~A} 2 \mathrm{~s}$ \\
\hline \multirow[t]{11}{*}{ ART Deputy Director } & $\begin{array}{l}\text { Assists ART director in accomplishing their R2A2s and acts for } \\
\text { the director in their absence. }\end{array}$ \\
\hline & $\begin{array}{l}\text { Communicates program direction and expectations to technical } \\
\text { leads and WPMs. }\end{array}$ \\
\hline & $\begin{array}{l}\text { Provides guidance to technical leads for budget planning, and } \\
\text { oversees budget development. }\end{array}$ \\
\hline & $\begin{array}{l}\text { Oversees execution of work scope to ensure completion on } \\
\text { schedule and within budget. }\end{array}$ \\
\hline & $\begin{array}{l}\text { Communicates performance and issues to NTDs, DOE-NE } \\
\text { program lead, and DOE field office representatives. }\end{array}$ \\
\hline & Ensures implementation of applicable QA programs. \\
\hline & $\begin{array}{l}\text { Participates in DOE-NE ART Program monthly performance } \\
\text { status teleconference. }\end{array}$ \\
\hline & Participates in annual ART program reviews. \\
\hline & $\begin{array}{l}\text { Provides skilled and qualified resources to perform work scope. } \\
\text { Prepares integrated priority list (IPL) in response to multi-year } \\
\text { budget call. }\end{array}$ \\
\hline & Authorizes baseline changes. \\
\hline & Approves milestone deliverables. \\
\hline \multirow[t]{9}{*}{ ART Project Managers } & $\begin{array}{l}\text { Develop and maintain baseline work scope, schedules, and } \\
\text { budgets and oversee the execution of work to ensure it is } \\
\text { performed within the baselines established in the control } \\
\text { account plans (CAPs). }\end{array}$ \\
\hline & $\begin{array}{l}\text { Provide monthly performance reporting in PICS:NE where } \\
\text { applicable. }\end{array}$ \\
\hline & $\begin{array}{l}\text { Participate in DOE-NE ART Program monthly performance } \\
\text { status teleconference. }\end{array}$ \\
\hline & Prepare milestone completion notification documentation. \\
\hline & Prepare Baseline Change Proposals when needed. \\
\hline & Maintain lifecycle baselines for their areas of responsibility. \\
\hline & $\begin{array}{l}\text { Work with technical leads/WPMs to establish priorities for } \\
\text { planned work and available resources within established } \\
\text { funding levels. }\end{array}$ \\
\hline & Work with WPMs to develop staffing plans. \\
\hline & $\begin{array}{l}\text { Provide monthly progress reports and status on Performance } \\
\text { Evaluation Measurement Plan milestones and Notable } \\
\text { Outcomes to management. }\end{array}$ \\
\hline
\end{tabular}




\begin{tabular}{|c|c|c|c|}
\hline $\begin{array}{l}\text { ADVANCED REACTOR TECHNOLOGIES } \\
\text { PROGRAM MANAGEMENT PLAN }\end{array}$ & $\begin{array}{l}\text { Identifier: } \\
\text { Revision: } \\
\text { Effective Date: }\end{array}$ & $\begin{array}{l}\text { PLN-2494 } \\
17 \\
02 / 07 / 2019\end{array}$ & Page: 19 of 43 \\
\hline
\end{tabular}

Table 1. (continued).

\begin{tabular}{|c|c|}
\hline Position & $\mathrm{R} 2 \mathrm{~A} 2 \mathrm{~s}$ \\
\hline ART Technical Leads & $\begin{array}{l}\text { Communicate program direction to technical staff. } \\
\text { Prioritize work scope within technical area. } \\
\text { Plan annual work scope, schedule and budget. } \\
\text { Identify milestones and deliverables. } \\
\text { Execute work on schedule and within budget. } \\
\text { Oversee all technical aspects within their respective technical } \\
\text { area. } \\
\text { Provide monthly performance reporting in PICS:NE. } \\
\text { Participate in DOE-NE ART Program monthly performance } \\
\text { status teleconference. } \\
\text { Perform work in accordance with applicable procedures and } \\
\text { requirements. } \\
\text { Participate in applicable annual ART program review meetings. } \\
\text { Identify necessary resources and/or skills to perform work } \\
\text { scope. } \\
\text { Propose baseline changes, as applicable. }\end{array}$ \\
\hline ART Licensing Director & $\begin{array}{l}\text { Works with DOE-NE program director to develop ART } \\
\text { Licensing Program direction, priorities, and milestones. } \\
\text { Communicates program direction and expectations to technical } \\
\text { leads and WPMs. } \\
\text { Integrates priorities within technology area. } \\
\text { Allocates funding within technology areas. } \\
\text { Ensures work performed within respective campaign is } \\
\text { consistent with program objectives and provides benefit. } \\
\text { Communicates performance status and issues to DOE-NE } \\
\text { program director. } \\
\text { Performs final review and approval of Level } 1 \text { and } 2 \text { milestone } \\
\text { deliverables. } \\
\text { Ensures implementation of applicable QA program. } \\
\text { Participates in DOE-NE ART Program monthly performance } \\
\text { status teleconference. } \\
\text { Participates in annual ART program review meetings, as } \\
\text { applicable. } \\
\text { Provides skilled and qualified resources to perform work scope. } \\
\text { Prepares IPL input in response to multi-year budget call. } \\
\text { Authorizes baseline changes. } \\
\text { Coordinates with the NRC, environmental and state regulators, } \\
\text { and ART personnel to ensure all work performed supports } \\
\text { licensing and regulatory needs. }\end{array}$ \\
\hline
\end{tabular}




\begin{tabular}{|c|c|c|c|}
\hline $\begin{array}{l}\text { ADVANCED REACTOR TECHNOLOGIES } \\
\text { PROGRAM MANAGEMENT PLAN }\end{array}$ & $\begin{array}{l}\text { Identifier: } \\
\text { Revision: } \\
\text { Effective Date: }\end{array}$ & $\begin{array}{l}\text { PLN-2494 } \\
17 \\
02 / 07 / 2019\end{array}$ & Page: 20 of 43 \\
\hline
\end{tabular}

Table 1. (continued).

\begin{tabular}{|c|c|}
\hline Position & $\mathrm{R} 2 \mathrm{~A} 2 \mathrm{~s}$ \\
\hline ART MR Technology Area Lead & $\begin{array}{l}\text { Works with DOE-NE program director to develop ART MR } \\
\text { Program direction, priorities, and milestones. } \\
\text { Communicates program direction and expectations to technical } \\
\text { leads, and WPMs. } \\
\text { Integrates priorities within technology area. } \\
\text { Allocates funding within technology areas. } \\
\text { Ensures work performed within respective campaign is } \\
\text { consistent with program objectives and provides benefit. } \\
\text { Communicates performance status and issues to DOE-NE } \\
\text { program director. } \\
\text { Performs final review and approval of Level } 1 \text { and } 2 \text { milestone } \\
\text { deliverables. } \\
\text { Ensures implementation of applicable QA program. } \\
\text { Participates in DOE-NE Nuclear Technology R\&D monthly } \\
\text { performance status teleconference. } \\
\text { Participates in DOE-NE ART Program monthly performance } \\
\text { status teleconference. } \\
\text { Participates in annual ART program review meetings, as } \\
\text { applicable. } \\
\text { Provides skilled and qualified resources to perform work scope. } \\
\text { Prepares IPL input in response to multi-year budget call. } \\
\text { Authorizes baseline changes. }\end{array}$ \\
\hline ART QA Engineer & $\begin{array}{l}\text { Conducts QA audits, communicate new or changed QA } \\
\text { initiatives, and assists ART management and staff with QA } \\
\text { issues. } \\
\text { This position has sufficient authority, direct access to } \\
\text { responsible levels of management, organizational freedom and } \\
\text { access to work to perform this function, including sufficient } \\
\text { independence from cost and schedule when opposed to safety- } \\
\text { function considerations. These verification functions include: } \\
\text { 1) identifying quality problems, 2) initiating, recommending, or } \\
\text { providing solutions to quality problems through designated } \\
\text { channels, 3) verifying implementation of solutions, 4) assuring } \\
\text { that further processing, delivery, installation, or use is } \\
\text { controlled until proper disposition of a nonconformance, } \\
\text { deficiency or unsatisfactory condition has occurred. }\end{array}$ \\
\hline ART Program Support Staff & $\begin{array}{l}\text { Provide support to other ART personnel in the daily operations } \\
\text { of ART. } \\
\text { Implement ART QAP requirements in accordance with } \\
\text { applicable implementing procedures. }\end{array}$ \\
\hline
\end{tabular}




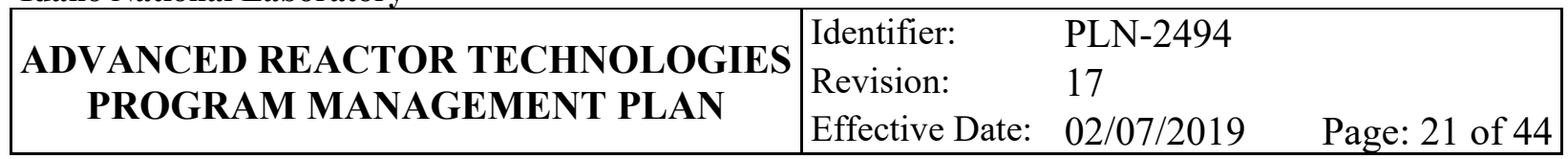

\subsection{Organization}

The ART organization is shown in Figure 1.

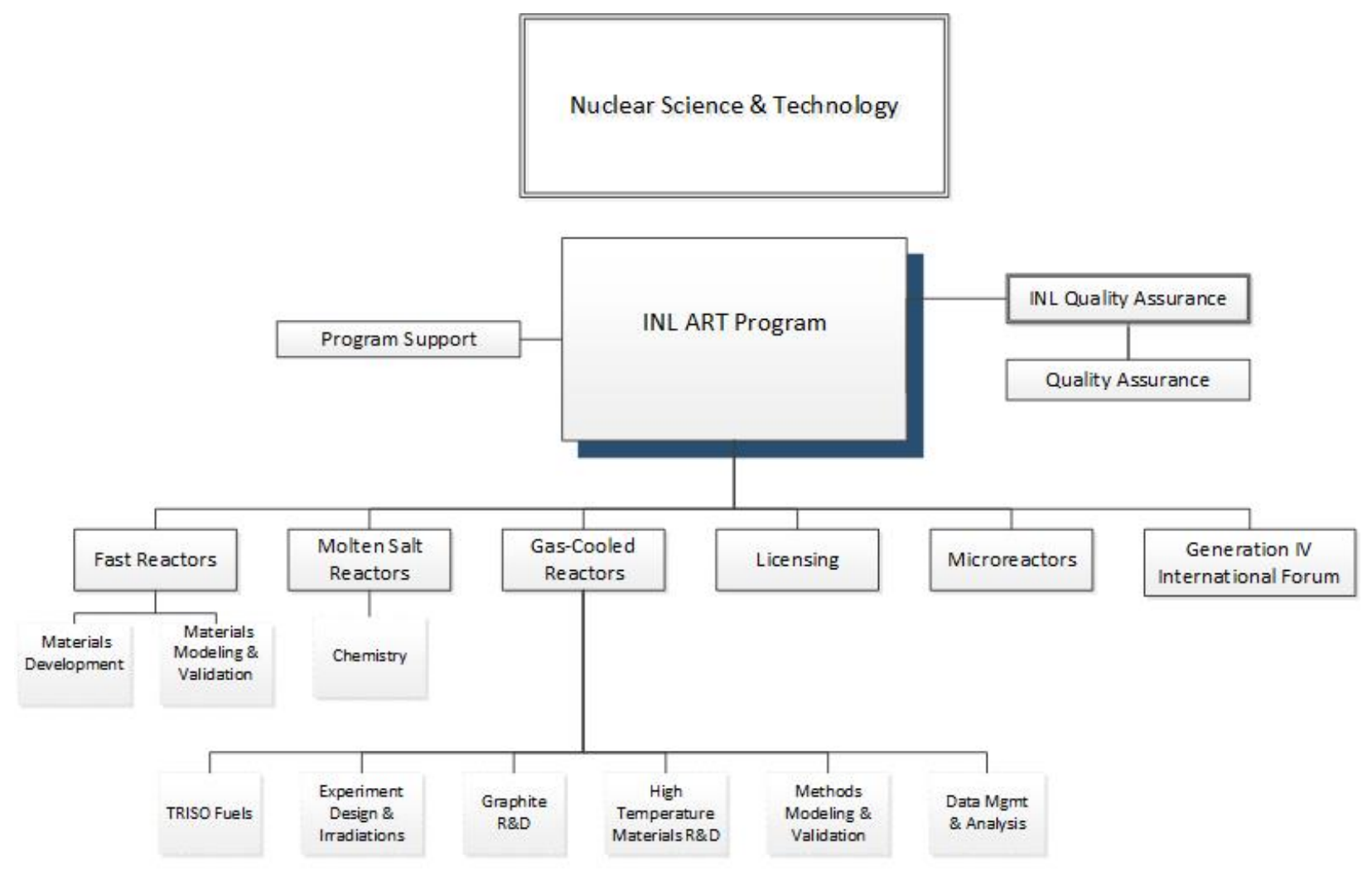

Figure 1. Advanced Reactor Technologies organization. 


\begin{tabular}{|c|lll|}
\hline $\begin{array}{c}\text { ADVANCED REACTOR TECHNOLOGIES } \\
\text { PROGRAM MANAGEMENT PLAN }\end{array}$ & Identifier: & PLN-2494 & \\
& Revision: & 17 & \\
& Effective Date: & $02 / 07 / 2019$ & Page: 22 of 43 \\
\hline
\end{tabular}

\subsection{Program Interfaces: External and Internal}

Program interfaces are identified in Table 2.

Table 2. Program interfaces

\begin{tabular}{|c|c|c|}
\hline Program Interface & Point of Contact & Description \\
\hline $\begin{array}{l}\text { DOE Office of Nuclear Energy } \\
\text { counterpart }\end{array}$ & $\begin{array}{l}\text { DOE-NE } \\
\text { representative }\end{array}$ & $\begin{array}{ll}\text { - } & \text { Biweekly AGR Fuels } \\
\text { teleconferences } \\
\text { - } & \text { Monthly PICS:NE reporting } \\
\text { - } & \text { Monthly DOE-NE-52 Advanced } \\
\text { Reactor Deployment performance } \\
\text { reporting } \\
\text { - } \quad \text { Monthly DOE ART Program } \\
\text { - } \text { performance reporting } \\
\text { - } \quad \text { Annuarterly technical reports } \\
\text { - } \text { submittal } \\
\text { - Annual 5-year IPL budget call } \\
\text { - } \text { submittal } \\
\text { Annual program review meetings }\end{array}$ \\
\hline $\begin{array}{l}\text { DOE Idaho Operations Office } \\
\text { technical monitor and budget } \\
\text { counterpart }\end{array}$ & $\begin{array}{l}\text { DOE-ID } \\
\text { representatives }\end{array}$ & $\begin{array}{ll}\text { - } & \text { Biweekly AGR Fuels } \\
& \text { teleconferences } \\
\text { - } & \text { Monthly PICS:NE reporting } \\
\text { - } & \text { Performance Evaluation and } \\
& \text { Measurement Plan status } \\
\text { - } & \text { Quarterly technical reports } \\
\text { - } & \text { Annual execution-year budget } \\
\text { - } & \text { Anbmittal } \\
\text { - } & \text { Annual 5-year IPL budget call } \\
\text { - Annual program review meetings }\end{array}$ \\
\hline ORNL and/or ANL & $\begin{array}{l}\text { Laboratory partners } \\
\text { in R\&D }\end{array}$ & $\begin{array}{ll}\text { - } & \text { MPO or IEWO } \\
\text { - } & \text { Biweekly AGR Fuels } \\
\text { teleconferences } \\
\text { - } \\
\text { - } & \text { Auarterly technical reports } \\
\end{array}$ \\
\hline Universities & University partners & $\begin{array}{l}\text { - Subcontracts direct to INL } \\
\text { - Subcontracts through Nuclear } \\
\text { Energy University Program } \\
\text { - } \quad \text { INL technical lead oversight }\end{array}$ \\
\hline
\end{tabular}




\begin{tabular}{|c|lll|}
\hline $\begin{array}{c}\text { ADVANCED REACTOR TECHNOLOGIES } \\
\text { PROGRAM MANAGEMENT PLAN }\end{array}$ & Identifier: & PLN-2494 & \\
& Revision: & 17 & \\
& Effective Date: & $02 / 07 / 2019$ & Page: 23 of 43 \\
\hline
\end{tabular}

Table 2. (continued).

\begin{tabular}{|c|c|c|}
\hline Program Interface & Point of Contact & Description \\
\hline $\begin{array}{l}\text { Babcock \& Wilcox Nuclear } \\
\text { Operations Group-Lynchburg, VA }\end{array}$ & Fuel fabrication & $\begin{array}{ll}\text { - } & \text { Subcontract/releases } \\
\text { - } & \text { Weekly phone calls } \\
\text { - } & \text { Biweekly AGR Fuels } \\
& \text { teleconferences } \\
\text { - } & \text { Quarterly technical reports } \\
\text { - } & \text { Annual program review meetings } \\
\text { - } & \text { Triennial supplier qualification } \\
& \text { audit } \\
\end{array}$ \\
\hline Consultants & $\begin{array}{l}\text { Unique technical } \\
\text { skills }\end{array}$ & $\begin{array}{l}\text { - } \text { Subcontracts } \\
\text { - } \quad \text { Technical coordination teams } \\
\text { - } \text { Phone calls (as necessary) } \\
\text { - Annual program review meetings } \\
\text { - } \quad \text { Formal Technical Coordination } \\
\quad \text { Team meeting (as required) } \\
\end{array}$ \\
\hline NRC & Licensing activities & $\begin{array}{l}\text { - Review Licensing submittals } \\
\text { - Transmittal of applicable INL } \\
\text { reports }\end{array}$ \\
\hline $\begin{array}{l}\text { National codes and standards } \\
\text { development committees }\end{array}$ & HTM and Graphite & $\begin{array}{l}\text { - } \quad \text { Meeting minutes (as necessary) } \\
\text { - } \quad \text { Phone calls (as necessary) } \\
\text { - } \quad \text { Participation in code meetings } \\
\text { - } \quad \text { Annual update report } \\
\end{array}$ \\
\hline $\begin{array}{l}\text { ASME Standards Technology, } \\
\text { LLC/DOE Gen IV Reactor Materials } \\
\text { Project }\end{array}$ & HTM and Graphite & $\begin{array}{l}\text { - } \quad \text { Meeting minutes (as necessary) } \\
\text { - } \quad \text { Phone calls (as necessary) } \\
\text { - } \quad \text { Participation in code meetings }\end{array}$ \\
\hline
\end{tabular}




\begin{tabular}{|c|lll|}
\hline $\begin{array}{c}\text { ADVANCED REACTOR TECHNOLOGIES } \\
\text { PROGRAM MANAGEMENT PLAN }\end{array}$ & Identifier: & PLN-2494 & \\
& Revision: & 17 & \\
& Effective Date: & $02 / 07 / 2019$ & Page: 24 of 43 \\
\hline
\end{tabular}

Table 2. (continued).

\begin{tabular}{|c|c|c|}
\hline Program Interface & Point of Contact & Description \\
\hline $\begin{array}{l}\text { INL facilities and organizations: } \\
\text { - } \text { ATR Operations } \\
\text { - } \text { HFEF } \\
\text { - } \text { Scheduling and Integration } \\
\text { - } \text { Test Train Assembly Facility } \\
\text { - User working groups } \\
\text { - } \text { Neutron Radiography Reactor } \\
\text { - Fuel Conditioning Facility } \\
\text { - } \text { Anockup Area } \\
\text { - } \text { Electron Microscopy Laboratory) } \\
\text { - } \text { QA } \\
\text { - Environing Department } \\
\text { - Health including RadCon } \\
\text { - } \text { Engineering } \\
\text { - Cabrication/Machine shops } \\
\text { Senter for Advanced Energy }\end{array}$ & $\begin{array}{l}\text { Facilities and service } \\
\text { organizations }\end{array}$ & $\begin{array}{ll}\text { - } & \text { Biweekly ATR/MFC Users } \\
\text { - } & \text { Working Group } \\
\text { - } & \text { Detailed operating instructions } \\
\text { - } & \text { Laboratory instructions } \\
\text { - } & \text { Experiment safety assurance } \\
& \text { package } \\
\text { - } & \text { Engineering job } \\
\text { - } & \text { As low as reasonably achievable } \\
\text { - } & \text { reviews } \\
\text { - } & \text { Tadiological work permits } \\
\text { - } & \text { Quarterly Nuclear Materials } \\
\text { Experiments Execution Process } \\
\text { (LWP-20700) Metrics meeting }\end{array}$ \\
\hline
\end{tabular}

\section{EXECUTION-YEAR BASELINE PLANNING}

Each year, in early summer, preliminary draft funding guidance for the upcoming fiscal year is provided by DOE-NE. Based on this guidance and the technical program plans, the ART deputy director, project managers, control account managers (CAMs), and WPMs develop an IPL. The IPL is used by the ART deputy director to assign scope and initial funding to the CAMs. The IPL is then translated into a planning package for consideration by DOE-NE. The planning package presents the proposed work scope at a control account level, including Level 2 milestones and allocation of funding among various national laboratories. This allows DOE-NE to evaluate the priorities, work scope, and funding across the entire ART Program and make adjustments accordingly. DOE-NE approval of planning packages allows the performance-measurement baseline development process to continue to the more detailed work-package phase.

Performance measurement baselines are developed based on DOE-NE agreed upon work scope and funding. Baselines are developed in both the INL internal system and in the DOE-NE PICS:NE. INL's performance measurement baselines consist of INL work-authorization documents (IWADs), including both CAPs and WPs, budget spreads, and resource-loaded schedules. Working with the WPMs, project managers assist in the development of WPs, including work scope, milestones, deliverables and assumptions, plus schedules, budgets, detailed cost-estimate sheets, and basis of estimates. CAMs then 


\begin{tabular}{|c|c|c|c|}
\hline $\begin{array}{l}\text { ADVANCED REACTOR TECHNOLOGIES } \\
\text { PROGRAM MANAGEMENT PLAN }\end{array}$ & $\begin{array}{l}\text { Identifier: } \\
\text { Revision: } \\
\text { Effective Date: }\end{array}$ & $\begin{array}{l}\text { PLN-2494 } \\
17 \\
02 / 07 / 2019\end{array}$ & Page: 25 of 43 \\
\hline
\end{tabular}

develop CAPs that summarize the information provided in the WPs; however, only Level 1, 2, and 3 external milestones are captured in CAPs. IWADs are reviewed and approved by the WPM, CAM, and Project and Financial Controls (PFC) representative. Final, approved IWADs are maintained by ART PFC personnel. PFC representatives input the resource and schedule information into INL projectmanagement systems to obtain formal pricing estimates and Level 3 schedules.

A corresponding, but different form of WP is also prepared in DOE-NE PICS:NE ${ }^{12}$ to identify major activities, budget baselines, milestones (Level 1, 2, 3, and 4), deliverables, and assumptions. In this system, activities are identified at a higher, summary level. To accommodate the provision of status for milestone performance in the process used by DOE-NE (and discussed in Section 6.3.3), all budgets must be tied to a milestone and/or level-of-effort activity. Each PICS:NE WP is submitted for review and approval through DOE-NE PICS:NE.

Consistent with the agreed-upon budget and associated scope, DOE-NE issues a program execution guidance letter to DOE-ID authorizing the scope and funding to be appropriated to INL. Typically, the initial guidance letter addresses only the period of continuing resolution until Congress and the Administration formally establish and approve the annual funding appropriation.

\subsection{Milestones and Deliverables}

The following is provided as guidance in planning and reporting of milestones.

\subsubsection{Milestone Definitions}

Level 1 milestones are high-level accomplishments that are reportable to DOE-HQ executive management. They are defined by DOE-HQ and directed to be included, where appropriate, into the baseline.

Level 2 milestones are external commitments to DOE-NE and represent key accomplishments of the ART program. A work package with funding $>\$ 500 \mathrm{~K}$ would be expected to generate at least one such milestone; however, there is not a set number of Level 2 milestones required per work package value. More significantly, milestones must be important relative to the overall objectives of the technical area. Completion dates for Level 2 milestones cannot be changed. Thus, careful consideration must be given to the milestone definition, deliverable description, and completion date because these are firm schedule commitments. Level 2 milestone deliverables require approval through the DOE-NE technical manager. Formal correspondence establishing the actual milestone completion date and attaching the milestone deliverables are issued to DOE-NE and DOE-ID under the signature of the ART director as the Level 2 milestones are completed.

Level 3 milestones are external commitments to the ART program NTDs. They also represent important program accomplishments, but are less time-critical than Level 2 milestones. Important interimprogress reports and limited funding activities would be included. A rough rule of thumb is one Level 3 milestone for each $\$ 300 \mathrm{~K}$ of funding within a work package. However, the number of Level 3 milestones should be dictated by the nature and scope of the work, not strictly by the value of the work package. Delays in completing Level 3 milestones will be tracked in PICS:NE; however, TAL-approved justification in PICS:NE monthly performance reporting is adequate approval for late accomplishment. The impact of a delayed Level 3 milestone on a Level 2 milestone needs to be understood and addressed accordingly. Level 3 milestone deliverables are also distributed to DOE-NE, but only require approval through the NTD.

Level 4 milestones are laboratory internal milestones serving to provide interim products supporting Level 3 milestones. Level 4 milestone deliverables are also distributed to DOE-NE, but only require approval through the TAL. 


\begin{tabular}{|c|lll|}
\hline $\begin{array}{c}\text { ADVANCED REACTOR TECHNOLOGIES } \\
\text { PROGRAM MANAGEMENT PLAN }\end{array}$ & Revision: & PLN-2494 & \\
& Effective Date: & $02 / 07 / 2019$ & Page: 26 of 43 \\
\hline
\end{tabular}

\subsubsection{Milestone Expectations}

The following points should be considered in the development and completion of milestones:

- Plan for success. Consider things that could go wrong, and plan contingency accordingly.

- Milestones should not be established for activities impacted by things over which the organization has little or no control (e.g., activities impacted by ATR operating schedule).

- Level 2 milestones cannot be changed, and their outcome affects evaluation of DOE-NE performance, as well as that of the ART Program.

- Those responsible for milestones and deliverables need to be involved in the development process and well aware of the expectations.

- Avoid milestone completion dates of September 30. Stagger milestones throughout the fiscal year to prevent an overload of milestones coming due at the same time; where possible, consider scheduling Level 2 milestones to fall within each quarter.

- Give considerable thought to the milestone and meaning and intent of the deliverable; a discontinuity between them could result in a milestone being considered unmet.

- Milestones are completion of an action (e.g., completion of a test). Deliverables are the objective evidence that the action was completed (e.g., test report).

- Milestone and deliverable titles need to be clearly understandable as stand-alone statements because they are often communicated separately out of context of the work package. For example, "Complete testing of three samples" doesn't identify what type of samples, and the statement could be mistaken to pertain to any one of several programs (e.g., Fuels, Graphite or HTM) when communicated separately from the work package (e.g., in monthly reports or DOE updates).

- Deliverable titles should match milestone titles as closely as possible, or at least be consistent; even slight differences can alter the meaning and cause confusion between what was accomplished and what was documented and delivered.

- Ensure milestone and deliverable descriptions in PICS:NE are consistent with the milestone and deliverable titles because the descriptions and titles are different inputs in PICS:NE.

- WPMs need to discuss milestone progress with responsible people at least monthly, including issues, support needed, and status of the deliverable.

- Milestone deliverables must be uploaded into PICS:NE for the milestone to be considered complete.

\subsubsection{Deliverable Expectations}

The following points should be considered in the development and completion of deliverables:

- Authors are responsible for the completeness, accuracy, and quality of their deliverables.

- Deliverables should be in their final state (i.e., reviewed by authors and a tech-edited, quality product) when provided to management for review and approval.

- Deliverables should be ready for management review one month in advance of their due dates for Level 1 and 2 milestones and two weeks in advance of the due dates for Level 3 milestones.

- In general, draft documents should not be deliverables.

- A deliverable should be the final version of the objective evidence. 


\begin{tabular}{|c|lll|}
\hline ADVANCED REACTOR TECHNOLOGIES & Identifier: & PLN-2494 & \\
PROGRAM MANAGEMENT PLAN & Revision: & 17 & \\
& Effective Date: & $02 / 07 / 2019$ & Page: 27 of 43 \\
\hline
\end{tabular}

- If the milestone is for completion of an interim activity, the deliverable should be the final version of an interim or preliminary report.

- There are a few exceptions with respect to draft documents being deliverables; for example, when a document is designated to go to an outside agency for input/review prior to finalization. However, even in those cases, the "draft" should be in a near-final state (i.e., reviewed and a techedited, quality product) prior to being transmitted to the outside agency.

- All deliverables must be tech-edited, formatted, reviewed and processed through the Lab Review System (LRS) for external release prior to distribution.

- Identify whether limited distribution applies and, if so, provide justification for limiting distribution, e.g., Cooperative Research and Development Agreement, Non-Disclosure Agreement, proprietary, etc.

- Per DOE-NE direction, "Project Controlled Information" markings are not an acceptable option for limiting distribution

- Limited distribution needs to be discussed with the ART deputy director on a case-by-case basis to determine appropriate handling and marking.

- Use ART Program templates to ensure necessary approvals are obtained. Contact ART Records Management and Document Control regarding applicable templates.

- Deliverables should be of the form in which they were identified and approved in PICS:NE. If a different form of deliverable is later deemed more appropriate, work with the CAM as early as possible to obtain the associated DOE-NE federal manager's approval of the alternate form and process a Baseline Change Proposal, if necessary.

- Level 1 and 2 Milestone Deliverables

- Require ART director's or deputy director's approval before issuance and upload into PICS:NE

- Allow at least one month to process deliverables (for technical editing, review and comment resolution, and LRSLRS processing)

- Issue these deliverables under a cover letter from the ART director.

- Level 3 Milestone Deliverables

- Require ART director's or deputy director's approval before issuance and upload into PICS:NE

- Allow at least two weeks to process deliverables (for technical editing, review and comment resolution, and LRS processing)

- Issue these deliverables via email from the ART director.

- Level 4 Milestones Deliverables

- $\quad$ Require CAM approval before issuance and upload into PICS:NE

- Allow adequate time, based on form of deliverable, to process deliverables (for technical editing, review and comment resolution, and LRS processing)

- Issued via email from the ART director.

- Deliverable must be uploaded into PICS:NE for milestone to be considered complete.

\subsection{Capital Equipment}

All funding is initially provided as operating dollars. For capital equipment (movable, tangible items) purchased, constructed, or fabricated in-house, including major modifications or improvements to any capital equipment with a useful life of 2 years or more and a cost of $\$ 500,000$ or more (including adders), 


\begin{tabular}{|c|lll|}
\hline $\begin{array}{c}\text { ADVANCED REACTOR TECHNOLOGIES } \\
\text { PROGRAM MANAGEMENT PLAN }\end{array}$ & Identifier: & PLN-2494 & \\
& Revision: & 17 & \\
& Effective Date: & $02 / 07 / 2019$ & Page: 28 of 43 \\
\hline
\end{tabular}

requestors must submit an INL funding determination request. When appropriate, the operating dollars are converted to capital dollars via DOE-ID approval, and a unique charge number is assigned by the PFC representative.

\section{OUT YEAR BUDGET CALL}

\subsection{Work Scope Identification}

Near the start of each calendar year, DOE-NE issues a call for budget priorities, starting two fiscal years prior to and extending for an additional three to five fiscal years. The process is similar to that described in Section 4 for execution-year baseline planning. WPMs are responsible for identifying work scope and associated funding needs by fiscal year. However, due to the multiyear nature of the projections, carryover is not taken into account. The NTDs collect input from their respective WPMs and compile it in a format provided by DOE-NE.

\subsection{Prioritization}

Once again, DOE-NE provides a target budget value for the year of focus, which is two fiscal years away. WPMs prioritize their respective activities, considering their technology needs. Once prioritized, the activities are summarized by the NTDs in blocks of approximately $\$ 1 \mathrm{M}$, or as communicated in the guidance. Summary activity blocks should be based on activities of relatively similar priority, rather than restricted to activities within the same work package, because a work package could contain both highand low-priority items that need to be kept separate for prioritization purposes.

NTDs consolidate and prioritize input across work packages, considering overall program needs. The work scope within the target value and $\pm 20 \%$ of the target values for funding are marked, assuming the final budget value will fall somewhere within that range. The result is a priority list at the campaign or technology area level, proposed to DOE-NE for their review and concurrence or comment. This multiyear priority list also serves as a basis for execution-year planning, taking into account any changes that might have occurred in the meantime.

\section{PROJECT CONTROL AND REPORTING}

\subsection{Work Breakdown Structure and Dictionary}

The ART work-breakdown structure for FY-19 is provided in Appendix A.

\subsection{Activity Work Authorization}

LWP-3420, "Laboratory Work Authorization and Funds Management," 13 defines the process, responsibilities, and documentation for assigning and accepting funds and work authorization for INL directly funded work. Under the existing system, DOE funding authorization is received via the DOEapproved funding program. DOE-ID issues a work authorization form to INL to authorize work. The INL funds administrator issues a funds authorization to the INL funds manager (e.g., ART director).WPMs working with the PFC representative then establish charge numbers for tracking the activity costs and provide authorization to personnel to use the assigned charge numbers.

\subsection{Performance Measurement Baseline}

Performance baselines establish core elements and activities required to measure and manage performance. As an R\&D program, ART has selected a tailored approach for earned-value management, based on the associated risk. 


\begin{tabular}{|c|lll|}
\hline $\begin{array}{c}\text { ADVANCED REACTOR TECHNOLOGIES } \\
\text { PROGRAM MANAGEMENT PLAN }\end{array}$ & Identifier: & PLN-2494 & \\
& Revision: & 17 & \\
& Effective Date: & $02 / 07 / 2019$ & Page: 29 of 43 \\
\hline
\end{tabular}

Earned-value methods to measure accomplishment of work are established for each WP during the planning phase. Many earned-value methods are available for measurement of progress, but the two most common methods used by the ART are percent complete and level of effort (LOE).

\subsubsection{Earned Value Management Level of Effort}

The LOE method is used for those scheduled activities that do not have discrete deliverables. This method is generally applied to management and project-support efforts. Budgets for LOE-scheduled activities must still have a documented cost estimate and basis of estimates, and be time phased to properly reflect when project work will be accomplished. The earned value amount for LOE activities equals the time-phased budget such that, by definition, no schedule variance results. However, a cost variance is still possible.

\subsubsection{Earned-value Management Percent Complete}

Earned-value management is used for performance measurement in the INL reporting system. The percent-complete method is used for activities that have technical deliverables. This earned value method allows WPMs to use their best judgment in determining the cumulative percent complete status at the end of each accounting period.

Each month, WPMs provide status on individual, scheduled activities with their percentage of completion. This information is provided to the PFC representative, who enters it into the project management system. The percent complete is converted to a budgeted cost-of-work-performed earned value by applying the percentage of work completed to the activity's total budget.

WPMs and CAMs are then responsible for evaluating cost and schedule-status performance relative to the approved baseline. Each cost and/or schedule variance exceeding reporting thresholds $( \pm 10 \%$ and $\$ 25 \mathrm{~K}$ cumulative) requires a variance analysis that addresses the cause, impact, and corrective action with its schedule. This information is reviewed and summarized by the project manager and reported monthly to the NS\&T associate laboratory director at the control-account level.

The WPMs, along with the CAM, must recognize, develop, and implement timely, effective corrective actions to control budgets and schedules within reporting thresholds. Cost performance is calculated using the following cost variance formula:

$C V \%=\frac{C V}{B C W P} \times 100$

Cost Performance Index $=\frac{B C W P}{A C W P}$

where:

$\mathrm{CV}=$ cost variance $=\mathrm{BCWP}-\mathrm{ACWP}$

$\mathrm{BCWP}=$ budgeted cost of work performed

ACWP $=$ actual cost of work performed.

Scheduled performance is calculated using the following schedule variance formula:

$S V \%=\frac{S V}{B C W S} \times 100$

Schedule Performance Index $=\frac{B C W P}{B C W S}$

where:

$\mathrm{SV}=$ schedule variance $=\mathrm{BCWP}-\mathrm{BCWS}$ 


\begin{tabular}{|c|c|c|c|}
\hline $\begin{array}{l}\text { ADVANCED REACTOR TECHNOLOGIES } \\
\text { PROGRAM MANAGEMENT PLAN }\end{array}$ & $\begin{array}{l}\text { Identifier: } \\
\text { Revision: } \\
\text { Effective Date: }\end{array}$ & $\begin{array}{l}\text { PLN-2494 } \\
17 \\
02 / 07 / 2019\end{array}$ & Page: 30 of 43 \\
\hline
\end{tabular}

$\mathrm{BCWP}=$ budgeted cost of work performed

BCWS $=$ budgeted cost of work scheduled.

\subsubsection{Milestone Status Performance Measurement}

Monthly performance measurement reporting is also entered into PICS:NE. However, PICS:NE employs a milestone-status system, ${ }^{14}$ rather than earned-value measurements. In the milestone status system, all planned budgets are assigned to a milestone or level-of-effort activity. Current period performance is based on anticipation of whether the milestones are expected to be completed on schedule, ahead of schedule, or behind schedule. If a milestone is determined to be on schedule, the activity is also considered to be on schedule for the current period, with no resulting schedule variance. If the milestone is indicated to be ahead of or behind schedule, the WPM must input a percent complete for the current period (which may result in a reportable schedule variance) and a revised milestone-completion date. In any case, a cost variance may ensue. Each cost or schedule variance exceeding reporting thresholds $( \pm 10 \%$ and $\$ 25 \mathrm{~K}$ cumulative) requires a variance analysis that addresses the cause, impact, and corrective action with schedule. For milestone status performance purposes, cost variances can be attributed to costs being less than or great than those planned for the work performed (i.e., definition of cost variance under earned value performance), as well as those costs associated with schedule without regard for actual performance (i.e., not incurring costs for work planned, but not performed, or incurring costs for work not planned, but performed). After monthly performance has been submitted at the work-package level, the CAM provides a rollup summary of all work packages within the control account for DOE-NE program management review.

\subsection{Estimate at Completion}

Another important performance metric is an estimate at completion (EAC). Beginning in April, and monthly thereafter for the remainder of the FY, WPMs perform a detailed monthly EAC analysis. The purpose of this analysis is to predict the year-end costs by evaluating the remaining scope for each activity and estimating the cost to complete it. The EAC is the sum of cumulative actual costs and the estimate to complete. For each WP, the EAC is compared to the authorized funding, and corrective actions are taken as needed. Such actions could include work-scope reductions to ensure authorized funding is not exceeded or work-scope additions to make use of excess funding generated through cost efficiencies (see Appendix B).

\subsection{Baseline Change Control}

\subsubsection{Purpose}

The purpose of baseline change control is to provide a formal mechanism for managing changes to the performance-measurement baseline

\subsubsection{Performance-measurement Baseline Change}

INL is responsible for determining and managing changes to its performance-measurement baseline (PMB). INL PMB change control is managed in accordance with process guidelines outlined in INL Form 415.14, "Baseline Change Proposal,"15 and will comply with LWP-7390, "Work Scope Management Process." 16

A PMB change will be completed when any one of the following conditions exists:

- New work resulting from direction by the contracting officer or ART director, new regulatory requirements, or a change to a record of decision outside of the initial statement of work

- Budget reductions by the government or customer 


\begin{tabular}{|c|lll|}
\hline $\begin{array}{c}\text { ADVANCED REACTOR TECHNOLOGIES } \\
\text { PROGRAM MANAGEMENT PLAN }\end{array}$ & Identifier: & PLN-2494 & \\
& Revision: & 17 & \\
& Effective Date: & $02 / 07 / 2019$ & Page: 31 of 43 \\
\hline
\end{tabular}

- Contracting-officer direction or contracting-officer initiated actions or events that have demonstrable material effect on the performance of the contract

- Changes to the level of mandatory services prescribed by tenant agreements

- Contractor inability to meet commitments because of funding limitations, such as those caused by Continuing Resolution

- Acceleration or slippage of project milestones as directed by the ART director or customer

- Use of management reserve for additional work scope

- Use of cost efficiencies towards additional work scope

- Changes in priorities, requiring change in work scope.

Baseline change proposals (BCPs) are classified as internal or external, based on the extent of the change and approval requirements. Change control thresholds are listed in Table 3 and authorization levels $(\mathrm{A}=$ approval; $\mathrm{C}=$ concurrence $)$ are listed in Table 4 . All new scope and changes made to the approved execution year plan (scope, schedule, or budget) fall under the change control process.

Table 3. INL Baseline change control thresholds.

\begin{tabular}{|l|l|l|l|}
\hline $\begin{array}{l}\text { Change } \\
\text { Type }\end{array}$ & Level 2 & Level 3 & Level 4 \\
\hline $\begin{array}{l}\text { Technical } \\
\text { Baseline }\end{array}$ & Any scope change. & & \\
\hline $\begin{array}{l}\text { Schedule } \\
\text { Baseline }\end{array}$ & $\begin{array}{l}\text { Any schedule change } \\
\text { that affects external } \\
\text { Level 1, 2, 3, or 4 } \\
\text { milestones. }\end{array}$ & $\begin{array}{l}\text { Any schedule change } \\
\text { that affects an internal } \\
\text { milestone. }\end{array}$ & $\begin{array}{l}\text { Any schedule change } \\
\text { that does not affect an } \\
\text { external Level 1, 2, 3, } \\
\text { or 4 milestone or an } \\
\text { internal milestone. }\end{array}$ \\
\hline $\begin{array}{l}\text { Budget } \\
\text { Baseline }\end{array}$ & $\begin{array}{l}\text { Any budget change that } \\
\text { affects the net total } \\
\text { budget of a control } \\
\text { account. }\end{array}$ & $\begin{array}{l}\text { Any budget change that } \\
\text { does not affect the net } \\
\text { total budget of a control } \\
\text { account. }\end{array}$ & $\begin{array}{l}\text { Any budget change that } \\
\text { does not affect the net } \\
\text { total budget of a work } \\
\text { package. }\end{array}$ \\
\hline
\end{tabular}

Table 4. Baseline change authorization.

\begin{tabular}{|l|c|c|c|}
\hline Change Authorization & Level 2 & Level 3 $^{\mathrm{a}}$ & Level 4 $^{\mathrm{a}}$ \\
\hline ART Funds Manager/Project Director & A & & \\
\hline ART LWBS Level 3 or 4 Program Manager & A & & \\
\hline ART LWBS Level 5 Subprogram Project Manager & A & A & \\
\hline ART LWBS Level 6 CAM & A & A & A \\
\hline Nuclear Programs Business Lead & C & C & C \\
\hline Environmental, Safety, and Health Manager (as required) & C & C & C \\
\hline
\end{tabular}

${ }^{a}$ Approved copies of Level 2, 3 and 4 BCPs are available to DOE by request. 


\begin{tabular}{|c|lll|}
\hline $\begin{array}{c}\text { ADVANCED REACTOR TECHNOLOGIES } \\
\text { PROGRAM MANAGEMENT PLAN }\end{array}$ & $\begin{array}{lll}\text { Revision: } \\
\text { Effective Date: }\end{array}$ & $\begin{array}{l}\text { PLN-2494 } \\
\text { PRI/2019 }\end{array}$ & Page: 32 of 43 \\
\hline
\end{tabular}

Similarly, changes are also made to the PICS:NE PMB, for which change control is managed in accordance with "Program Information Collection System: Nuclear Energy (PICS:NE) - Program Management Procedure for Baseline Change Control."

\section{REPORTING}

Reporting is used to communicate cost and schedule performance, accomplishments, new developments, and issues. Reporting requirements are derived from the needs and requirements of the various organizations that provide funding to or interface with the ART program. Reports are oral, written, or in presentation form, depending on the purpose and target audience. The reports required by the program are listed below:

- Monthly cost and schedule status input to the INL Project Management System

- Monthly cost and schedule status input to PICS:NE

- Monthly DOE-NE ART Program review via video conference

- Monthly DOE-NE-52 Advanced Reactor Deployment Program review with NTDs via teleconference

- Monthly status report to NS\&T Business Review

- Quarterly Advanced Reactor Technologies (ART):Very High Temperature Reactor (VHTR) Research and Development (R\&D)

- Quarterly Report technical reports to DOE

- Annual program review meetings with DOE, ART Co-NTDs and TALs.

\section{RISK MANAGEMENT}

Project risk management is a continuous process where risks are identified, monitored, and mitigated. The goal of risk management is to improve project performance and decrease the likelihood of cost overruns, schedule delays, and compromises in quality and safety.

The ART program encounters many types of risk, including programmatic budget and schedule risks, technical risks, facility availability risks, personnel resource availability risks, and political risks. Program risks will be assessed and managed in accordance with MCP-7350, "Project Risk Management." 17 Due to the programmatic risks associated with R\&D activities, PLN-3247, "Risk Management Plan for the Next Generation Nuclear Plant Project," 18 has been prepared, which includes ART activities related to HTRs and addresses risk identification, analysis, response, monitoring, and control. Program success hinges on the success of R\&D efforts, such as the development of alloys for heat exchangers that can withstand the requisite high temperatures.

\section{ENVIRONMENTAL, SAFETY, HEALTH AND QUALITY ASSURANCE}

\subsection{Environmental}

Company environmental requirements are outlined in Laboratory-wide Manual 8, Environmental Protection and Compliance. All activities are performed in accordance with LWP-8000, "Environmental Instructions for Facilities, Processes, Materials, and Equipment." ${ }^{19}$ Under LWP-8000, environmental checklists are completed for potentially hazardous activities. The completed checklists are then used to determine the level of environmental review required before a proposed activity can proceed. 


\begin{tabular}{|c|lll|}
\hline $\begin{array}{c}\text { ADVANCED REACTOR TECHNOLOGIES } \\
\text { PROGRAM MANAGEMENT PLAN }\end{array}$ & $\begin{array}{lll}\text { Revision: } \\
\text { Effective Date: }\end{array}$ & $\begin{array}{l}\text { PLN-2494 } \\
\text { PRI/2019 }\end{array}$ & Page: 33 of 43 \\
\hline
\end{tabular}

\subsection{Safety and Health}

Company safety and health requirements are outlined in Laboratory Requirements Document (LRD)-14700, "Worker Safety and Health: General Program Requirements."

INL uses the Integrated Safety Management System (ISMS) established in PDD-1004, "Integrated Safety Management System," ${ }^{21}$ to prescribe the procedures and processes necessary to do work safely. The fundamental premise of ISMS is to perform work safely. This is achieved by implementing formal processes that provide rigor and discipline to work execution. ISMS uses a top-down process for performing work and the associated requirements at each level. The framework for ISMS is organized around the following five core functions:

- Define the work

- Identify and analyze the hazards

- Develop and implement controls

- Perform the work

- Provide feedback for improvement.

All operations and maintenance work will be performed in accordance with approved company policies and procedures for radiation protection, industrial hygiene, and industrial safety.

\subsubsection{Integrated Safety Management System}

ART supports each employee's timeout and stop-work authority per LWP-14002, ${ }^{22}$ Timeout and Stop Work Authority," and the Voluntary Protection Program's Bill of Rights. Every employee and subcontractor has the responsibility and authority to initiate stop work for any environmental, safety, or quality issue. A stop work requires the issue to be reported to the cognizant authority and the execution work manager.

It is each employee's responsibility to think in terms of safety as work documents are reviewed and input is provided. Each employee is also encouraged to contribute to the safety of the program by participating in safety shares at all meetings.

\subsubsection{Radiation Protection}

Company radiation protection requirements are outlined in LRD-15001, Radiological Control Manual. $^{23}$

\subsection{Quality Assurance}

ART activities are performed in accordance with PLN-2690, "Idaho National Laboratory Advanced Reactor Technologies Technology Development Office Quality Assurance Program Plan.”6 The ART QA program, as described in PLN-2690, is compliant with "Nuclear Technology Research and Development (NTRD) Quality Assurance Program Document." ${ }^{24}$ PLN-2690 is reviewed at least annually and updated as needed.

\subsubsection{Records Management}

ART has established project files that are maintained in hard-copy or electronic form and managed in accordance with PLN-4653, "INL Records Management Plan," 25 which implements the requirements of LWP-1202, "26 "Records Management" and PDD-11, "Records Management." 27 


\begin{tabular}{|c|c|c|c|}
\hline $\begin{array}{l}\text { ADVANCED REACTOR TECHNOLOGIES } \\
\text { PROGRAM MANAGEMENT PLAN }\end{array}$ & $\begin{array}{l}\text { Identifier: } \\
\text { Revision: } \\
\text { Effective Date: }\end{array}$ & $\begin{array}{l}\text { PLN-2494 } \\
17 \\
02 / 07 / 2019\end{array}$ & Page: 34 of 43 \\
\hline
\end{tabular}

\subsubsection{Software Quality Assurance}

ART creates and tests several software programs associated with modeling and analysis activities. These programs are managed in accordance with LWP-20000-01, "Conduct of Research Plan." 28

LWP-20000-01 provides instructions for identification of applicable software quality assurance (SQA) requirements in support of R\&D activities and applies to software used at INL to support ART. Form 562.41, "Software Management Plan and Life Cycle Documentation for Research and Development Activities," 29 covers the development, acquisition, modification, maintenance, operation, and retirement of software. It pertains to the control of support software and the application of standards, conventions, and other work practices that support the software life cycle.

\subsubsection{Data Management Plan}

Data from ART experiments reside in the NDMAS and will ultimately be used to support licensing applications for commercial HTGRs. NDMAS provides storage and validation, qualification, and analysis capabilities. PLN-2709, "Nuclear Data Management and Analysis System Plan;"7 describes the R\&D data that will be managed and analyzed with NDMAS and various attributes, qualification and validation activities, collection methods, and storage plans for the data. PLN-2709 also discusses the methods used for qualification and validation of data, such as control charting, correlation analysis, and monitoring summary statistics.

\subsubsection{Configuration Management}

Effective configuration management is obtained by implementing requirements that provide for:

- Consistent identification of items requiring configuration control

- Management of requirements and documentation applicable to the items

- Control of changes to the items.

The ART program will maintain configuration management on all systems and test assemblies directly associated with ART R\&D efforts by following existing company procedures. Essential systems will be maintained using company procedures as follows:

- Design Control: PDD-10000, "Conduct of Engineering"30

- Document Control: LWP-1201, "Document Management,"26 and MCP-2875, "Proper Use and Maintenance of Laboratory Notebooks." 31

- Software: LWP-20000-01, "Conduct of Research Plan"28

- QA Records: LWP-1202, "Records Mangement."26

\subsubsection{Personnel Indoctrination, Training, and Qualification}

Each member of ART personnel must have current employee position description, verified evidence of education and experience for applicable positions, and documented indoctrination and training tailored for the work being performed.

Each employee has an individual training plan, as described in LWP-12003, "New and Transferred Employee Training Requirements." 32 Each employee's manager is responsible for identifying the job function and responsibilities assigned to the employee. The manager and training coordinator will perform a job-task analysis, assign job codes for the employee's job functions and responsibilities, and identify training needs. 


\begin{tabular}{|c|lll|}
\hline $\begin{array}{c}\text { ADVANCED REACTOR TECHNOLOGIES } \\
\text { PROGRAM MANAGEMENT PLAN }\end{array}$ & $\begin{array}{lll}\text { Revision: } \\
\text { Effective Date: }\end{array}$ & $\begin{array}{l}\text { PLN-2494 } \\
\text { PRI/2019 }\end{array}$ & Page: 35 of 43 \\
\hline
\end{tabular}

\section{PROJECT CLOSURE}

All ART program facility change forms, work orders, technical procedures, and subcontracts must be formally closed (not just completed) before program closeout can be declared. The program will follow GDE-70, "General Project Management Method," Section V, Project Closeout. ${ }^{34}$ The program team will prepare a checklist of closeout activities to be scheduled. The program records will be transferred, by letter, to the Electronic Document Management System as part of program closeout at the completion of the program. A final completion report will be prepared in accordance with GDE-70-V. A roadmap documenting the distribution of program files will be provided.

\section{APPENDICES}

Appendix A, ART FY-19 Work Breakdown Structure

Appendix B, Estimate-at-Completion Example

\section{REFERENCES}

1. Public Law 109-58, 2005, "Energy Policy Act of 2005," United States Congress, August 8, 2005

2. PLN-3636, "Technical Program Plan for the Advanced Reactor Technologies Technology Development Office/Advanced Gas Reactor Fuel Development and Qualification Program"

3. PLN-2804, "Next Generation Nuclear Plant Steam Generator and Intermediate Heat Exchanger Materials Research and Development Plan"

4. PLN-2497, "Graphite Technology Development Plan"

5. PLN-2498, "Next Generation Nuclear Plant Methods Technical Program Plan"

6. PLN-2690, "INL ART Technology Development Office Quality Assurance Program Plan"

7. PLN-2709, "Nuclear Data Management and Analysis System Plan"

8. LWP-3420, "Laboratory Work Authorization and Funds Management"

9. PLN-3295, "Training and Indoctrination Plan for the INL ART Technology Development Office"

10. American Society of Mechanical Engineers NQA-1, "Quality Assurance Requirements for Nuclear Facility Applications," American Society of Mechanical Engineers, 2008, 2009a

11. NRC Regulatory Guide 1.203, "Transient and Accident Analysis Methods," Nuclear Regulatory Commission, 2005

12. PICS:NE FY-18 Work Package User Guide, dated September 1, 2017

13. LWP-3420, "Laboratory Work Authorization and Funds Management"

14. PICS:NE Milestone Tracking Reporting Status User Guide, dated December 5, 2017

15. Form 415.14, "Baseline Change Proposal"

16. LWP-7390, "Work Scope Management"

17. MCP-7350 "Project Risk Management"

18. PLN-3247, "Risk Management Plan for the Next Generation Nuclear Plant Project"

19. LWP-8000, "Environmental Instructions for Facilities, Processes, Materials and Equipment"

20. LRD-14700, "Worker Safety and Health: General Program Requirements", Manual 14C 


\begin{tabular}{|c|c|c|c|}
\hline $\begin{array}{l}\text { ADVANCED REACTOR TECHNOLOGIES } \\
\text { PROGRAM MANAGEMENT PLAN }\end{array}$ & $\begin{array}{l}\text { Identifier: } \\
\text { Revision: } \\
\text { Effective Date: }\end{array}$ & $\begin{array}{l}\text { PLN-2494 } \\
17 \\
02 / 07 / 2019\end{array}$ & Page: 36 of 43 \\
\hline
\end{tabular}

21. PDD-1004, "Integrated Safety Management System"

22. LWP-14002, "Timeout and Stop Work Authority"

23. LRD-15001, Radiological Control Manual

24. "Nuclear Technology Research and Development (NTRD) Quality Assurance Program Document," Rev. 4, July 5, 2017

25. PLN-4653, "INL Records Management Plan"

26. LWP-1202, "Records Management"

27. PDD-11, "Records Management Plan"

28. LWP-20000-01, "Conduct of Research Plan".

29. INL Form 562.41 "Software Management Plan and Life Cycle Documentation for Research and Development Activities

30. PDD-10000, "Conduct of Engineering"

31. MCP-2875, "Proper Use and Maintenance of Laboratory Notebooks"

32. LWP-12003, "New and Transferred Employee Training Requirements," Rev. 7, 2018

33. LWP-1201, "Document Management"

34. GDE-70-V, "General Project Management Method - Project Closeout," Section V, Rev. 4, 2018 


\section{Appendix A}

\section{ART FY-19 Work Breakdown Structure}




\begin{tabular}{|c|lll|}
\hline $\begin{array}{c}\text { ADVANCED REACTOR TECHNOLOGIES } \\
\text { PROGRAM MANAGEMENT PLAN }\end{array}$ & Identifier: & PLN-2494 & \\
& Revision: & 17 & \\
& Effective Date: & $02 / 07 / 2019$ & Page: 38 of 43 \\
\hline
\end{tabular}

\section{Appendix A \\ FY-19 ART Work Breakdown Structure}

\begin{tabular}{|l|l|l|l|l|l|l|l|l|}
\hline C & C & 70 & & & & & Advanced Reactor Technologies (ART) & H Gougar \\
\hline C & C & 70 & 07 & & & & Advanced Reactor Technologies (ART) & H Gougar \\
\hline C & C & 70 & 07 & 01 & & & ART Program Management & D Croson \\
\hline C & C & 70 & 07 & 01 & 01 & & ART Program Management & D Croson \\
\hline C & C & 70 & 07 & 01 & 01 & 01 & Campaign Management and Integration & D Croson \\
\hline
\end{tabular}

\begin{tabular}{|l|l|l|l|l|l|l|l|l|}
\hline C & C & 70 & 07 & 02 & & & High Temperature Reactor R\&D & D Croson \\
\hline C & C & 70 & 07 & 02 & 01 & & GCR Fuel Development & T Mitchell \\
\hline C & C & 70 & 07 & 02 & 01 & 01 & AGR Fuels Planning and Reporting & T Mitchell \\
\hline C & C & 70 & 07 & 02 & 01 & 02 & AGR Fuel Fabrication & D Marshall \\
\hline C & C & 70 & 07 & 02 & 01 & 03 & AGR Fuel Irradiation & M Davenport \\
\hline C & C & 70 & 07 & 02 & 01 & 04 & AGR Fuel Post-Irradiation Examination & D Laug \\
\hline C & C & 70 & 07 & 02 & 01 & 05 & AGR Fuel Performance Modeling & W Skerjanc \\
\hline C & C & 70 & 07 & 02 & 01 & 06 & AGR Fuel Data Management and Analysis & M Plummer \\
\hline C & C & 70 & 07 & 02 & 01 & 07 & AGR Fuel Licensing Support & J Kinsey \\
\hline
\end{tabular}

\begin{tabular}{|l|l|l|l|l|l|l|l|l|}
\hline C & C & 70 & 07 & 02 & 02 & & GCR Methods, Modeling and Validation & D Croson \\
\hline C & C & 70 & 07 & 02 & 02 & 02 & Methods Experimental Validation & J Wolf \\
\hline C & C & 70 & 07 & 02 & 02 & 03 & Methods Core Simulation & G Strydom \\
\hline C & C & 70 & 07 & 02 & 02 & 07 & Methods International Collaborations & H Gougar \\
\hline
\end{tabular}

\begin{tabular}{|l|l|l|l|l|l|l|l|l|}
\hline C & C & 70 & 07 & 03 & & & ART Licensing & J C Kinsey \\
\hline C & C & 70 & 07 & 03 & 01 & & ART Safety and Licensing & T Mitchell \\
\hline C & C & 70 & 07 & 03 & 01 & 08 & Licensing Modernization Project & W Moe \\
\hline C & C & 70 & 07 & 03 & 01 & 09 & Regulatory Development and NRC Interaction & M Holbrook \\
\hline C & C & 70 & 07 & 03 & 01 & 10 & EPRI Support for Fuel LSTR & M Holbrook \\
\hline C & C & 70 & 07 & 03 & 01 & 11 & $\begin{array}{l}\text { Microreactor Regulatory Development and } \\
\text { NRC Interaction }\end{array}$ & M Holbrook \\
\hline
\end{tabular}




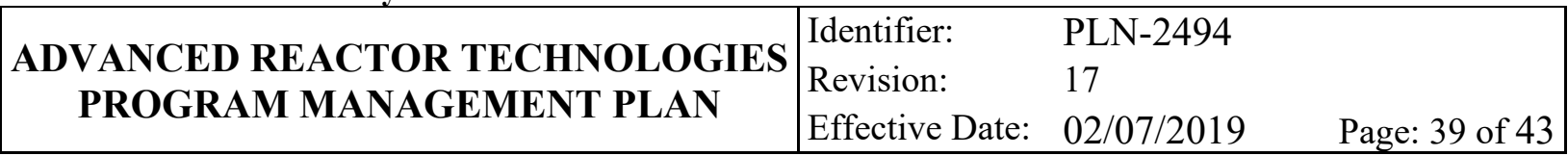

\begin{tabular}{|l|l|l|l|l|l|l|l|l|}
\hline C & C & 70 & 07 & 04 & & & GCR Advanced Materials Development & D Croson \\
\hline C & C & 70 & 07 & 04 & 01 & & High Temperature Materials & T Mitchell \\
\hline C & C & 70 & 07 & 04 & 01 & 01 & High Temperature Design Methodology & R Wright \\
\hline C & C & 70 & 07 & 04 & 01 & 02 & Long-Term VHTR Material Qualification & R Wright \\
\hline
\end{tabular}

\begin{tabular}{|l|l|l|l|l|l|l|l|l|}
\hline C & C & 70 & 07 & 04 & 03 & & Graphite Development and Qualification & M Davenport \\
\hline C & C & 70 & 07 & 04 & 03 & 01 & Graphite Planning and Reporting & M Davenport \\
\hline C & C & 70 & 07 & 04 & 03 & 02 & AGC Experiment Design & M Davenport \\
\hline C & C & 70 & 07 & 04 & 03 & 03 & Graphite Material Properties & W Windes \\
\hline C & C & 70 & 07 & 04 & 03 & 04 & Graphite Data Management and Analysis & M Davenport \\
\hline
\end{tabular}

\begin{tabular}{|l|l|l|l|l|l|l|l|l|}
\hline C & $\mathrm{C}$ & 70 & 07 & 06 & & & Program Assessment and Coordination & D Croson \\
\hline $\mathrm{C}$ & $\mathrm{C}$ & 70 & 07 & 06 & 01 & & General GIF Representation & T Mitchell \\
\hline $\mathrm{C}$ & $\mathrm{C}$ & 70 & 07 & 06 & 01 & 04 & General GIF Representation & B Hong \\
\hline $\mathrm{C}$ & $\mathrm{C}$ & 70 & 07 & 06 & 01 & 07 & GIF/WGSAR & J Kinsey \\
\hline
\end{tabular}

\begin{tabular}{|l|l|l|l|l|l|l|l|l|}
\hline $\mathrm{C}$ & $\mathrm{C}$ & 70 & 07 & 08 & & & Miscellaneous Projects & D Croson \\
\hline $\mathrm{C}$ & $\mathrm{C}$ & 70 & 07 & 08 & 01 & & X-Energy Technical Services & D Croson \\
\hline $\mathrm{C}$ & $\mathrm{C}$ & 70 & 07 & 08 & 01 & 01 & X-Energy Technical Services & D Croson \\
\hline
\end{tabular}

\begin{tabular}{|l|l|l|l|l|l|l|l|l|}
\hline C & C & 70 & 07 & 08 & 02 & & $\begin{array}{l}\text { Massachusetts Institute of Technology JA - } \\
\text { Future of Nuclear Power Study }\end{array}$ & D Croson \\
\hline C & C & 70 & 07 & 08 & 02 & 01 & $\begin{array}{l}\text { Massachusetts Institute of Technology JA - } \\
\text { Future of Nuclear Power Study }\end{array}$ & D Croson \\
\hline
\end{tabular}

\begin{tabular}{|l|l|l|l|l|l|l|l|l|}
\hline $\mathrm{C}$ & $\mathrm{C}$ & 70 & 07 & 08 & 04 & & PBMR CRADA & T Mitchell \\
\hline $\mathrm{C}$ & $\mathrm{C}$ & 70 & 07 & 08 & 04 & 01 & PBMR CRADA & T Mitchell \\
\hline
\end{tabular}

\begin{tabular}{|l|l|l|l|l|l|l|l|l|}
\hline $\mathrm{C}$ & $\mathrm{C}$ & 70 & 07 & 08 & 05 & & PHISICS for AREVA (FOA) & D Croson \\
\hline $\mathrm{C}$ & $\mathrm{C}$ & 70 & 07 & 08 & 05 & 01 & PHISICS for AREVA & D Croson \\
\hline
\end{tabular}

\begin{tabular}{|l|l|l|l|l|l|l|l|l|}
\hline $\mathrm{C}$ & $\mathrm{C}$ & 70 & 07 & 08 & 07 & & NRC Training on HTGR (MPO w/ANL) & D Croson \\
\hline $\mathrm{C}$ & $\mathrm{C}$ & 70 & 07 & 08 & 07 & 01 & NRC Training on HTGR & D Croson \\
\hline
\end{tabular}


ADVANCED REACTOR TECHNOLOGIES PROGRAM MANAGEMENT PLAN
Identifier: Revision: Effective Date: 02/07/2019

PLN-2494

17
Page: 40 of 43

\begin{tabular}{|l|l|l|l|l|l|l|l|l|}
\hline C & C & 70 & 07 & 09 & & & $\begin{array}{l}\text { Advanced Reactor Concept Development - XE } \\
\text { FOA }\end{array}$ & D Croson \\
\hline C & C & 70 & 07 & 09 & 01 & & Project Management - XE FOA & T Mitchell \\
\hline C & C & 70 & 07 & 09 & 01 & 01 & Progress Reporting - XE FOA & T Mitchell \\
\hline C & C & 70 & 07 & 09 & 02 & & Reactor Design Futherance - XE FOA & T Mitchell \\
\hline C & C & 70 & 07 & 09 & 02 & 01 & Graphite Qualification - XE FOA & T Mitchell \\
\hline C & C & 70 & 07 & 09 & 03 & & Fuel Development - XE FOA & T Mitchell \\
\hline C & C & 70 & 07 & 09 & 03 & 03 & Pre-irradiation Test Planning - XE FOA & T Mitchell \\
\hline C & C & 70 & 07 & 09 & 04 & & NRC Engagement - XE FOA & T Mitchell \\
\hline C & C & 70 & 07 & 09 & 04 & 01 & $\begin{array}{l}\text { Source Term Analysis Tool Development - XE } \\
\text { FOA }\end{array}$ & T Mitchell \\
\hline C & C & 70 & 07 & 09 & 04 & 02 & White Papers - XE FOA & T Mitchell \\
\hline
\end{tabular}

\begin{tabular}{|l|l|l|l|l|l|l|l|l|}
\hline C & $\mathrm{C}$ & 70 & 07 & 10 & & & Fast Reactors & D Croson \\
\hline $\mathrm{C}$ & $\mathrm{C}$ & 70 & 07 & 10 & 01 & & FR Advanced Materials Development & T Mitchell \\
\hline $\mathrm{C}$ & $\mathrm{C}$ & 70 & 07 & 10 & 01 & 01 & A709 Code Case Testing & R Wright \\
\hline $\mathrm{C}$ & $\mathrm{C}$ & 70 & 07 & 10 & 01 & 02 & A709 Development & R Wright \\
\hline $\mathrm{C}$ & $\mathrm{C}$ & 70 & 07 & 10 & 02 & & FR Methods Modeling and Validation & T Mitchell \\
\hline $\mathrm{C}$ & $\mathrm{C}$ & 70 & 07 & 10 & 02 & 01 & France Bilateral & G Palmiotti \\
\hline
\end{tabular}

\begin{tabular}{|l|l|l|l|l|l|l|l|l|}
\hline C & C & 70 & 07 & 11 & & & Molten Salt Reactors & D Croson \\
\hline C & C & 70 & 07 & 11 & 03 & & MSR Chemistry & D Croson \\
\hline C & C & 70 & 07 & 11 & 03 & 03 & MSR Chemistry & G Fredrickson \\
\hline
\end{tabular}

\begin{tabular}{|l|l|l|l|l|l|l|l|l|}
\hline C & $\mathrm{C}$ & 70 & 07 & 12 & & & Microreactors & S Bragg-Sitton \\
\hline $\mathrm{C}$ & $\mathrm{C}$ & 70 & 07 & 12 & 01 & & HALEU Environmental Assessment & S Bragg-Sitton \\
\hline $\mathrm{C}$ & $\mathrm{C}$ & 70 & 07 & 12 & 01 & 02 & HALEU Environmental Assessment & S Bragg-Sitton \\
\hline $\mathrm{C}$ & $\mathrm{C}$ & 70 & 07 & 12 & 02 & & Program Management and Integration & J Gehin \\
\hline $\mathrm{C}$ & $\mathrm{C}$ & 70 & 07 & 12 & 02 & 01 & Program Management & J Gehin \\
\hline $\mathrm{C}$ & $\mathrm{C}$ & 70 & 07 & 12 & 02 & 02 & Support to Department of Defense & J Gehin \\
\hline C & $\mathrm{C}$ & 70 & 07 & 12 & 03 & & Systems Integration and Analysis & J Gehin \\
\hline $\mathrm{C}$ & $\mathrm{C}$ & 70 & 07 & 12 & 03 & 01 & Integrated Systems Analysis & J Gehin \\
\hline C & $\mathrm{C}$ & 70 & 07 & 12 & 03 & 02 & Economic Performance and Market Analysis & J Gehin \\
\hline
\end{tabular}




\begin{tabular}{|c|lll|}
\hline $\begin{array}{c}\text { ADVANCED REACTOR TECHNOLOGIES } \\
\text { PROGRAM MANAGEMENT PLAN }\end{array}$ & $\begin{array}{lll}\text { Revifision: } \\
\text { Effective Date: }\end{array}$ & $\begin{array}{l}\text { PLN-2494 } \\
\text { RAT/2019 }\end{array}$ & Page: 41 of 43 \\
\hline
\end{tabular}

\begin{tabular}{|l|l|l|l|l|l|l|l|l|}
\hline C & C & 70 & 07 & 12 & 04 & & Demonstrate Support Capabilities & J Gehin \\
\hline C & C & 70 & 07 & 12 & 04 & 01 & Nonnuclear Testing and Demonstration & J O'Brien \\
\hline C & C & 70 & 07 & 12 & 04 & 02 & Heat Exchange/Power Conversion & D Guillen \\
\hline C & C & 70 & 07 & 12 & 04 & 03 & Nuclear Testing and Demonstration & M N Patterson \\
\hline C & C & 70 & 07 & 12 & 05 & & Technology Maturation & J Gehin \\
\hline C & C & 70 & 07 & 12 & 05 & 01 & High Temperature Moderator Materials & J Gehin \\
\hline C & C & 70 & 07 & 12 & 05 & 02 & Advanced Heat Removal & J Gehin \\
\hline C & C & 70 & 07 & 12 & 05 & 03 & Instrumentation and Sensors & J Gehin \\
\hline \multicolumn{10}{|c|}{} \\
\hline C & C & 70 & 07 & 12 & 06 & & Licensing/Regulatory & J Gehin \\
\hline C & C & 70 & 07 & 12 & 06 & 01 & Microreactor Regulatory Requirements & W Moe \\
\hline
\end{tabular}




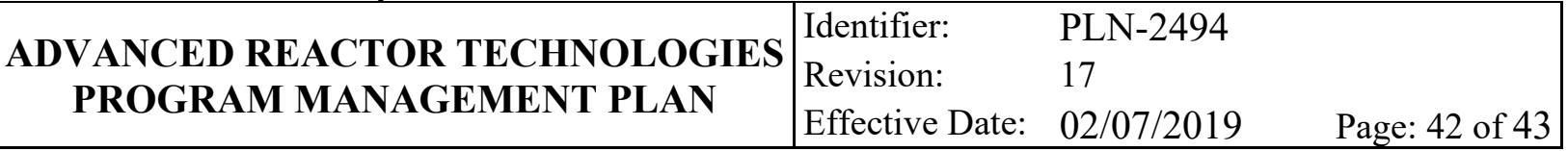

\section{Appendix B}

\section{Estimate-at-Completion Example}




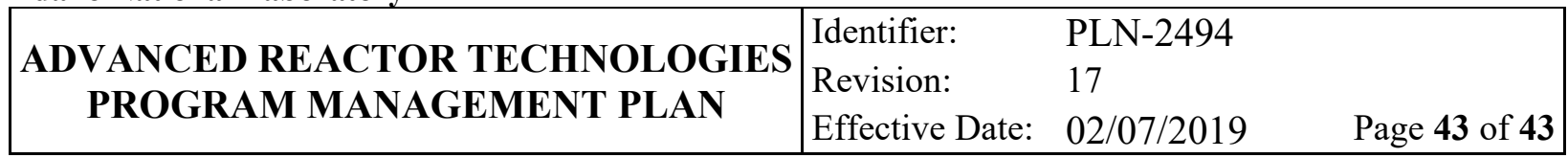

\section{Appendix B \\ Estimate-at-Completion Example}

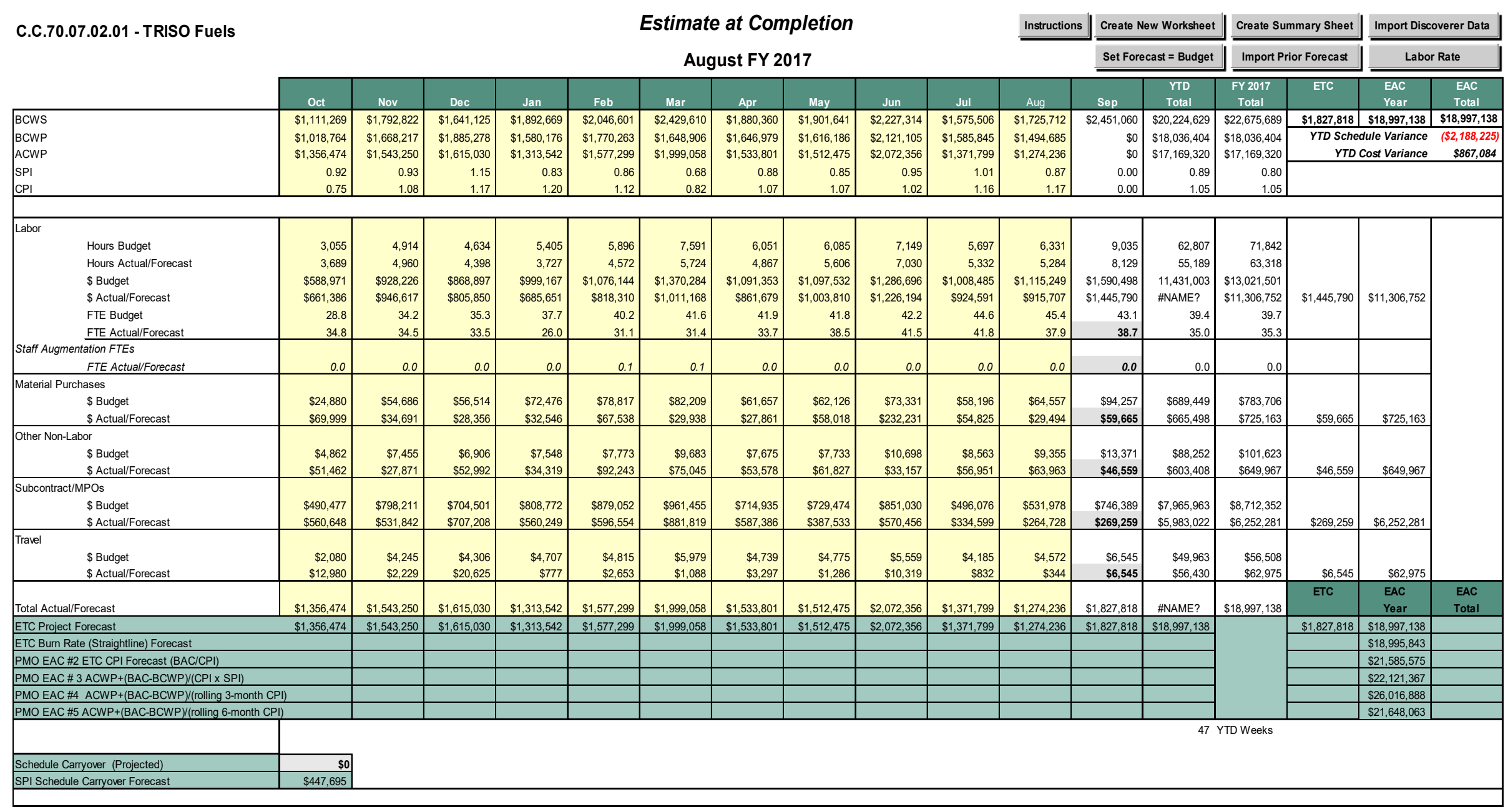

